九州大学学術情報リポジトリ

Kyushu University Institutional Repository

\title{
Brain pericytes : Emerging concepts and functional roles in brain homeostasis
}

\section{Kamouchi, Masahiro}

Department of Medicine and Clinical Science, Graduate School of Medical Sciences, Kyushu University

\section{Ago, Tetsuro}

Department of Medicine and Clinical Science, Graduate School of Medical Sciences, Kyushu University

\section{Kitazono, Takanari}

Department of Medicine and Clinical Science, Graduate School of Medical Sciences, Kyushu University

http://hdl. handle. net/2324/25464

出版情報：Cellular and Molecular Neurobiology. 31 (2)，pp. 175-193，2011-03. Springer US バージョン:

権利関係: (C) 2010 Springer Science+Business Media, LLC 


\section{Brain pericytes: emerging concepts and functional roles in brain homeostasis}

Masahiro Kamouchi, Tetsuro Ago, Takanari Kitazono

Department of Medicine and Clinical Science, Graduate School of Medical Sciences, Kyushu University

Corresponding author: Masahiro Kamouchi, MD, PhD

Maidashi 3-1-1, Higashi-ku, Fukuoka 812-8582, Japan

e-mail: kamouchi@intmed2.med.kyushu-u.ac.jp

Short title: Brain pericytes and brain homeostasis 


\begin{abstract}
Brain pericytes are an important constituent of neurovascular unit. They encircle endothelial cells and contribute to the maturation and stabilization of the capillaries in the brain. Recent studies have revealed that brain pericytes play pivotal roles in a variety of brain functions, such as regulation of capillary flow, angiogenesis, blood brain barrier, immune responses, and hemostasis. In addition, brain pericytes are pluripotent and can differentiate into different lineages similar to mesenchymal stem cells. The brain pericytes are revisited as a key player to maintain brain function and repair brain damage.
\end{abstract}

Key words: angiogenesis, blood brain barrier, mesenchymal stem cell, microvasculature, pericyte 


\section{Introduction}

Pericytes in the microvasculature were first described by Rouget et al. (Rouget 1873; Rouget 1879). Zimmerman et al. termed the cells "pericytes", since they are situated in the peri-endothelial space in the capillary (Zimmerman 1923). The cells have been long recognized as the cells that support the capillary, equivalent to arterial smooth muscle cells. However, increasing studies have unveiled a variety of physiological as well as pathological roles of these mysterious cells.

Pericytes are ubiquitously present in the capillaries in almost all tissues and organs. However, pericytes are most rich in the retina and brain (Frank et al 1987; Shepro and Morel 1993). The density of the pericytes is considered to be several-fold higher in the brain than in other organs, thus implying the importance of these cells in the brain (Frank et al 1987; Shepro and Morel 1993). During the preceding decade, it became evident that the cells regulate capillary flow, angiogenesis, the blood brain barrier, and immune responses in the brain (Hirschi and D'Amore 1996; Balabanov and Dore-Duffy 1998; Thomas 1999; Rucker et al 2000; Allt and Lawrenson 2001; Lai and Kuo 2005; Dore-Duffy 2008; Krueger and Bechmann 2010). Pericyte dysfunction may cause serious central nervous system (CNS) disorders. Moreover, recent progress in stem cell research has revealed that pericytes have the potential to differentiate into different cell lineages. These cells may play a pivotal role in repair and regeneration of brain tissue, since they have similar properties to mesenchymal stem cells.

There have been excellent reviews concerning the functional roles of pericytes (Hirschi and D'Amore 1996; Balabanov and Dore-Duffy 1998; Thomas 1999; Rucker et al 2000; Allt and Lawrenson 2001; Lai and Kuo 2005; Dore-Duffy 2008; Krueger and Bechmann 2010). We herein update the current understandings for pericyte physiology and pathophysiology, particularly in the brain.

\section{Morphology}

Brain pericytes are predominantly located in the capillaries. They are scarcely distributed in the arterioles and venules in the brain. The lumen of the capillaries is formed by endothelial cells, and pericytes surround their abluminal surface. The pericyte has prominent oval nuclei and several long extending processes. Primary processes elongate in the longitudinal axis along the capillaries, and secondary processes branch along the circumferential axis and penetrate into the basal membrane. The endothelial cells and pericytes closely contact each other by interdigitation. In addition, these cells are intimately connected 
with 'peg and socket' contacts, adhesion plaques, gap junctions, or tight junctions (Hirschi and D'Amore 1996; Rucker et al 2000; Allt and Lawrenson 2001). By means of these close interactions, they mutually communicate and transmit intercellular signals.

\section{Cell Markers}

There has been no specific marker to identify brain pericytes. The absence of specific immunochemical markers has hampered the progress of pericyte research. Generally, pericytes have been identified with a combination of positive and negative cell markers. The markers of the cells might vary, depending on the specificity of the species (human or other species), tissue (brain or other tissues), localization (pre-, mid-, or post-capillary), differentiation (immature or differentiated), and developmental stages (embryo or adult). For instance, microvascular pericytes derived from the mouse embryo brain and the human brain do not express $\alpha$-smooth muscle actin, whereas pericytes derived from the chicken embryo brain do express this protein (Gerhardt et al 2000). Kir6.1 is highly expressed in pericytes in the brain but is undetectable in pericytes in the skin and heart (Bondjers et al 2006).

The cell markers which have been suggested for pericytes are as follows: $\alpha$-smooth muscle actin, desmin, chondroitin sulfate proteoglycan marker NG2, RGS-5, CD140a, CD140b (PDGFR- $\beta$ ), aminopeptidases A and N, nestin, Sca-1, CD34 (pluripotential), 3G5 (monoclonal Ab ganglioside antigen), high molecular weight melanoma-associated antigen, $\mathrm{y}$-glutamyl transpeptidase, alkaline phosphatase, butyrylcholinesterase, FcR, CD4, CD11b, MHC class I, II, and vimentin (Table 1) (Nayak et al 1988; Kunz et al 1994; Balabanov and Dore-Duffy 1998; Thomas 1999; Guillemin and Brew 2004; Armulik et al 2005; Bondjers et al2006; Nisancioglu et al 2008; Paquet-Fifield et al 2009). Pericytes share cell markers with smooth muscle cells and with mesenchymal stem cells. The diverse expression pattern may be due to microenvironment-specified differentiation. Among various markers, PDGFR- $\beta$ and NG2 are widely used to detect pericytes along with the localization at pericapillary space in the brain.

\section{Functional Roles}

\section{Regulation of microcirculation}

\section{(1) Contractile activity}

Pericytes in the brain express contractile filaments and associated proteins, such as $\alpha$-isoform or 
muscle specific actin, myosin, tropomyosin, and cGMP-dependent protein kinase. Desmin or vimentin may be also expressed in the cells (Hirschi and D'Amore 1996; Rucker et al 2000; Allt and Lawrenson 2001; Bandopadhyay et al 2001; Bergers and Song 2005). Some studies reported that contractile proteins are expressed in pre- and post-capillary pericytes but rare in midcapillary pericytes (Nehls and Drenckhahn 1991; Boado and Pardridge 1994). However, it is also suggested that $\alpha$-smooth muscle actin is strongly expressed in a significant number of mid-capillary pericytes (Bandopadhyay et al2001). Although the expression level of these contractile proteins has been variously reported in brain pericytes, the amount of pericyte muscle actin is considered to be intermediate between endothelial cells and smooth muscle cells (Boado and Pardridge 1994).

The brain pericytes express the receptors for a variety of vasoactive substances, including adrenergic agonists, cholinergic agonists, histamine, serotonin, angiotensin II, endothelin-1, atrial natriuretic peptide, and ATP (Table 1) (Lee et al 1989; Takahashi et al 1989; Chakravarthy et al 1992; Ferrari-Dileo et al 1996; Matsugi et al 1997; McGinty et al 1999; Sakagami et al 1999; Pallone et al 2000; Pallone and Huang 2002). Patch clamp experiments revealed the expression of $P_{2} X_{7}, P_{2} Y_{4}, E T_{A}, P D G F R-\beta$, and the muscarinic receptor in freshly isolated pericytes (Puro 2007). Intracellular $\mathrm{Ca}^{2+}$, a key signal triggering contraction molecule, increases in response to various vasoactive substances in brain pericytes. Cultured retinal pericytes contracted or relaxed in accordance with the changes in intracellular $\mathrm{Ca}^{2+}$ (Wakisaka et al 2001; Kamouchi et al 2004; Oishi et al 2007). Electrophysiological studies also showed that muscarinic stimulation elevated intracellular $\mathrm{Ca}^{2+}$ levels and increased $\mathrm{Ca}^{2+}$-activated $\mathrm{Cl}^{-}$currents in freshly isolated rat retinal pericytes (Sakagami et al 1999). Spontaneous surges of $\mathrm{Ca}^{2+}$ or $\mathrm{Ca}^{2+}$ transients were observed in a portion of the pericyte during electrical neuron activity in vivo using an animal model (Hirase et al 2004). In cultured human brain microvascular pericytes, extracellular protons induced $\mathrm{Ca}^{2+}$ oscillation via reverse-mode $\mathrm{Na}^{+} / \mathrm{H}^{+}$ exchanger 1 (Nakamura et al 2008). Various ionic channels such as ATP-sensitive $\mathrm{K}^{+}$channels, $\mathrm{Ca}^{2+}$-activated $\mathrm{K}^{+}$channels, inwardly rectifying $\mathrm{K}^{+}$channels, voltage-dependent $\mathrm{K}^{+}$channels, and L-type voltage-dependent $\mathrm{Ca}^{2+}$ channels are expressed in brain pericytes (Li and Puro 2001; Puro 2007). Therefore, brain pericytes can contract following the increase in intracellular $\mathrm{Ca}^{2+}$, which is induced by vasoactive substances. The interplay between $\mathrm{Ca}^{2+}$ signals and membrane potentials finely modulates the contraction of the pericytes. 


\section{(2) Regulation of the capillary flow}

Pericytes are tightly attached to endothelial cells in capillaries. Adhesion plaques are important for transmitting the contraction of pericytes into the capillary diameter. The contraction of the pericytes along the circumferential axis leads to a reduced capillary diameter. It is generally accepted that capillary flow is predominantly regulated by the change in the diameter of precapillary arterioles. Therefore, the question of whether pericytes must contract arises.

Quite recently, direct evidence has been provided in whole-retina and cerebellar slices that pericytes control capillary diameter. Pericytes likely contribute to blood flow modulation in response to changes in neural activity (Peppiatt et al 2006). Reactive oxygen species cause a sustained increase in $\mathrm{Ca}^{2+}$ in human brain microvascular pericytes (Kamouchi et al 2007; Nakamura et al 2009). It has been also shown in the mouse brain that oxidative-nitrative stress-retained pericytes contracted, even after recanalization of an occluded middle cerebral artery (Yemisci et al 2009). The diameter of the capillary is not wide enough to allow several red blood cells to freely pass. Therefore, a reduction in capillary diameter may result in decreased passage or in entrapment of red blood cells (Figure 1). Impairment of microcirculation and ischemia-reperfusion injury may be induced by oxidative stress-induced pericyte contraction (Yemisci et al 2009).

In the retina, pericytes play an important role in the regulation of retinal blood flow (Wu et al 2003; Lombard 2006; Yamanishi et al 2006). It is possible that brain pericytes control the capillary blood supply in response to the activity of neurons. During brain hypoxia, poor pericyte relaxation may cause a critical decrease in capillary flow which cannot compensate for the lack of oxygen. A mismatch in the capillary flow to neuronal activity results in impairment of microcirculation and potentially underlies several CNS disorders.

\section{Angiogenesis}

\section{(1) Angiogenic process}

It is well known that pericytes play critical roles in both angiogenesis and vasculogenesis (Hirschi and D'Amore 1996; Gerhardt and Betsholtz 2003; Armulik et al 2005; Bergers and Song 2005; Hall 2006; von Tell et al 2006). In vivo experiments with a knockout mouse model clearly showed that the cells are involved in the stabilization and maturation of the microvasculature. Pericyte loss induces morphological changes in the brain capillary. A mouse model in which recruitment of pericytes was genetically ablated presented with 
endothelial hyperplasia, increased capillary diameter, and increased transendothelial permeability in the brain (Hellstrom et al 2001).

In the angiogenic process, the interaction between pericytes and endothelial cells is essential for vessel stability and maturation (Hirschi and D'Amore 1996; Gerhardt and Betsholtz 2003; Armulik et al 2005; Bergers and Song 2005; Hall 2006; von Tell et al 2006). The turnover of endothelial cells is slow in the capillary where pericytic coverage is rich. In contrast, detachment of pericytes from the abluminal surface of the capillary initiates the stimulation of endothelial cells. Activated endothelial cells degrade the extracellular matrix and dissociate from the basement membrane. The cells then migrate and proliferate into the interstitial space and form lumens (Figure 2). The tip of the newly formed vessel attracts pericytes, and the tubes are subsequently covered with pericytes, leading to vessel remodeling, maturation, and stabilization (Hirschi and D'Amore 1996; Gerhardt and Betsholtz 2003; Armulik et al 2005; Bergers and Song 2005; Hall 2006; von Tell et al 2006).

Another hypothesis is that pericytes stimulate and guide endothelial cells to form new vessels. Several studies have suggested that migrating pericytes precede angiogenesis and initiate the angiogenic process. Therefore, pericytes may contribute to the early growth of vessels as well as to the stabilization and maturation of newly formed vessels (Beck and D'Amore 1997; Hirschi et al 1999; Ozerdem and Stallcup 2003; Fukushi et al 2004; Virgintino et al 2007).

\section{(2) Angiogenic factors}

The interaction between pericytes and endothelial cells regulates migration, differentiation, and proliferation of both cell types. These cells can act directly or indirectly in an autocrine or paracrine manner, which regulates the maturation and stability of newly formed vessels. Signaling molecules, including growth factors and cytokines, are secreted from these cells and exert their actions by binding to cognate receptors (Figure 3). Intercellular communication between endothelial cells and pericytes is mediated by multiple signals (Armulik et al 2005; Braun et al 2007; Gaengel et al 2009). Three major receptor-ligand systems, transforming growth factor- $\beta$, angiopoietin, and platelet derived growth factor, regulate angiogenesis via the interaction of endothelial cells and pericytes. Other signaling pathways are also involved in angiogenesis and vasculogenesis (Table 1) (Armulik et al 2005). In addition to secreted molecules, cell surface proteins mediate signals through cell-cell or cell-extracellular matrix interactions (Figure 3). 
In this section, the signaling pathways involved in vasculogenesis and tumor- or ischemia-related angiogenesis are extensively reviewed not only in the brain, but also in all tissues and organs. We focus on the roles of pericytes in their mechanisms. Although these angiogenic mechanisms are probably involved in the brain as well as in other tissues, further studies are required to elucidate whether these processes are also related to CNS pericytes.

\section{1) Transforming growth factor- $\beta$}

Signal transduction by transforming growth factor (TGF)- $\beta$ pathway is essential for angiogenesis (Bertolino et al 2005). Genetic inactivation of the genes encoding TGF- $\beta$ in mice has revealed the pivotal role of this pathway in angiogenesis. TGF- $\beta$ family ligands are produced as dimeric precursor proteins, then are cleaved by proteases and secreted from endothelial cells. They bind to heteromeric complexes of type II and type I serine/threonine kinase transmembrane receptors in endothelial cells and pericytes. TGF- $\beta$ interacts with T $\beta R$ II and ALK5, but can also signal via ALK1 in endothelial cells. Endoglin can facilitate TRRII/ALK5 and TRRII/ALK1 signaling, which induce phosphorylation of Smad2/3 and Smad1/5. Activated Smads form complexes with Smad4 and translocate into the nucleus to induce gene transcription (Goumans et al 2009).

The interaction between endothelial cells and pericytes is required for production of latent TGF- $\beta$. An in vitro study revealed that coculture of bovine aortic endothelial cells and bovine retinal pericytes produces latent TGF- $\beta$ (Sato and Rifkin 1989). It was shown that endothelial cells produce TGF- $\beta 1$ and -2 , while smooth muscle cells produce TGF- $\beta 1$ (Sato et al 1990). The activation of TGF- $\beta 1$ was mediated by plasmin, whereas TGF- $\beta$ negatively controls plasmin activation by upregulation of plasminogen activator inhibitor-1 (Sato and Rifkin 1989; Sato et al 1990). Studies with immunoelectron micrographs revealed that TGF- $\beta$, urokinase plasminogen activator, and plasminogen colocalize at the sites of endothelial cell-pericyte interdigitations in newly-formed capillaries in human granulation tissues (Wakui et al 1997). Gap junction communication between endothelial cells and mesenchymal cells is required for TGF- $\beta$ activation. Endothelial-induced mural cell differentiation may be mediated by activation of TGF- $\beta$ through gap junction communication (Hirschi et al 2003).

TGF- $\beta$ derived from endothelial cells has positive autoregulatory effects on the expression, synthesis, and release of TGF- $\beta$. In endothelial cells, TGF- $\beta$ can promote differentiation via Alk5/Smad2/3 signaling, and proliferation and migration through Alk1/endoglin/Smad1/5 signaling (Armulik et al 2005; Gaengel et al 2009). 
TGF- $\beta$ produced by coculture of endothelial cells and retinal pericytes regulates endothelial functions. TGF- $\beta 1$ potently induces VEGFR-1 expression in endothelial cells, which prevents vessel loss induced by oxygen (Shih et al 2003). TGF- $\beta$ inhibits the endothelial cell growth (Antonelli-Orlidge et al 1989) and movement (Sato and Rifkin 1989), and induces apoptotic cell death of endothelial cells (Yan and Sage 1998).

TGF- $\beta$ signaling is important for proper differentiation of pericytes. TGF- $\beta$ induces the differentiation of $\mathrm{C} 3 \mathrm{H} / 10 \mathrm{~T} 1 / 2$ mesenchymal cells towards the smooth muscle cell/pericyte lineage with changes in phenotype- and cell-specific markers (Hirschi et al 1998; Ding et al 2004). TGF- $\beta 1$ increased $\alpha$-smooth muscle actin in human brain pericytes (Verbeek et al 1994) and was required for capillary-like structures by mediating the differentiation to pericytes (Darland and D'Amore 2001). On the other hand, $\mathrm{C} 3 \mathrm{H} / 10 \mathrm{~T} 1 / 2$ proliferation was not mediated by TGF- $\beta$ in the presence of endothelial cells (Hirschi et al 1999). The ablation of TGF- $\beta$ signaling by a TGF- $\beta$ type II receptor with a truncated $C$-terminal intracellular kinase domain demonstrated that TGF- $\beta 1$ signaling controls pericyte functions. TGF- $\beta$ accumulated $\alpha$-smooth muscle actin mRNA and protein in the bovine retinal pericytes but inhibited pericyte growth (Sieczkiewicz and Herman 2003). These results indicate that TGF- $\beta$ signaling promotes differentiation of pericytes and inhibits proliferation of pericytes. However, a recent study showed contradicting data, thus suggesting that TGF- $\beta$ was dispensable for the induction of vascular smooth muscle cells and pericytes (Lindskog et al 2006).

Hereditary hemorrhagic telangiectasia is caused by mutations in TGF- $\beta$ signaling (Fernandez et al 2006). Mice lacking endoglin and ALK-1 showed arterial-venous malformation (Li et al 1999; Urness et al 2000; Sorensen et al 2003). Endoglin-deficient mice die from defective vascular development. In this mouse, vasculogenesis was unaffected, whereas development of smooth muscle cells was impaired ( $\mathrm{Li}$ et al 1999). Endothelium-specific disruption of TGF- $\beta$ /ALK5 signaling caused a failure of the adjacent mesothelial cells to differentiate into smooth muscle cells. Exogenous TGF- $\beta 1$ rescued the phosphorylation of Smad2 and the differentiation of smooth muscle (Carvalho et al 2004). ALK1 inactivation of by gene targeting showed that ALK-1 was required for differentiation and the recruitment of vascular smooth muscle cells (Oh et al 2000). In the TGF- $\beta$ type 1 receptor-deficient mouse, hematopoiesis and development of hematopoietic progenitors remained intact. However, mesenchymal cells were not able to differentiate into smooth muscle cells with TGF- $\beta$ signaling (Larsson et al 2001). Taken together, inactivation of TGF- $\beta$ signaling impairs the differentiation of pericytes, which reduces the numbers of pericytes and smooth muscle cells and causes defective vessel formation. 


\section{2) Platelet derived growth factor-B}

Studies on platelet derived growth factors (PDGFs) and their receptors (PDGFRs) have established the roles of PDGF-B/PDGFR- $\beta$ pathways in vessel formation. The ligands are dimers of disulfide-linked polypeptide chains and act primarily as homodimers. PDGF-B is expressed in endothelial cells and PDGFR- $\beta$ in pericytes (Andrae et al 2008).

Genetic ablation of the PDGF-B/PDGFR- $\beta$ pathway revealed that these signals are a key regulator for maturation of new vessels. PDGF-B and PDGFR- $\beta$-deficient mouse embryos are lethal during late gestation due to vascular dysfunction in the brain. They lack microvascular brain pericytes and develop capillary microaneurysms, which rupture during the prenatal period (Lindahl et al 1997). In PDGF-B and PDGFR- $\beta$ knockout embryos, newly formed vessels in the brain showed endothelial hyperplasia with increased vessel diameter and hyperpermeability due to lack of brain pericytes, although microvessel density, length, and number of branchings were normal (Hellstrom et al 2001). Endothelium-specific ablation of PDGF-B generated viable mice. However, the pericyte density was low, which is associated with retinal microvascular abnormalities (Enge et al 2002). When cerebral angiogenesis in mice was induced by implanting a sandwich system of basic fibroblast growth factor (bFGF)/PDGF gel, the pericytes were rich in neocapillaries as induced by PDGF (Jariyapongskul et al 2003). In tumor angiogenesis, PDGFR- $\beta$ signaling is required for recruitment of progenitor perivascular cells and vessel maturation (Song et al 2005).

PDGF-B is highly expressed in migratory tip cells at the leading edge of an angiogenic sprout. On the other side, PDGFR- $\beta$ is expressed in perivascular mesenchymal cells or pericyte progenitor cells. Endothelial cells of sprouting capillaries synthesize and secrete PDGF-BB and induce the migration and proliferation of PDGFR- $\beta$-positive pericyte progenitor cells during vascular development (Ball et al 2007). The induction of pericytes from the perivascular mesenchyme may be initially induced by PDGF-independent signals, such as TGF- $\beta$. However, PDGF-BB derived from endothelial cells is necessary to recruit and cause proliferation of pericyte progenitors. Therefore, spatiotemporal changes in PDGF-B/ PDGFR- $\beta$ signals regulate microvasculature maturation by recruitment of brain pericytes (Lindahl et al 1997; Hellstrom et al 1999; Hellstrom et al 2001).

PDGF-BB is secreted from the endothelial cell surface and diffuses into the matrix. PDGF-BB binds to heparin and heparan sulfate proteoglycans in the pericellular matrix, and the high concentration of 
PDGF-BB is retained in the vicinity of the developing vessel. Consequently, PDGFR- $\beta$-positive pericyte progenitor cells migrate and proliferate along the growing vessel. The gradient of PDGF-BB formed by heparan sulfate proteoglycans is beneficial for localized regulation of pericytes at the leading edge of newly formed sprouts. It has been shown that reduction of N-sulfation attenuates PDGF-BB binding in vitro, and leads to pericyte detachment and impaired pericyte migration but not proliferation in the brain (Abramsson et al 2007). Therefore, appropriate structural features of heparan sulfate appear to be important to retain PDGF-BB and activate PDGFR- $\beta$ signaling in the brain (Abramsson et al 2007).

The overexpression of PDGF-BB upregulates stromal cell-derived factor (SDF)-1 $\alpha$ expression in endothelial cells in tumors. SDF-1 $\alpha$ increases the motility of pericytes, and the recruitment of these cells was inhibited by blockade of the SDF-1a/CXCR4 axis. Therefore, the SDF-1a/CXCR4 signaling axis may be important for PDGF-BB-induced pericyte recruitment within a tumor (Song et al 2009). In caveolin-1 deficient mice, tumor angiogenesis was promoted with a marked reduction in pericytes. In addition, the migration and outgrowth of smooth muscle cells/pericytes following PDGF-B was impaired. Therefore, caveolin-1 plays critical roles in the recruitment of pericytes via PDGF signaling (Dewever et al 2007). A recent study indicated that there were two cohorts of PDGF receptors in pericytes from neonatal foreskin. One was primarily confined to lipid rafts, specifically the caveolae, and the other was localized to non-raft compartments. These receptors were activated by soluble PDGF-B and membrane bound PDGF-B, which mediate distinct cellular functions. Cytoskeletal reorganization was only induced by soluble PDGF-B (Sundberg et al 2009). The recruitment of pericytes may be determined by the signal balance between the PDGF-B concentration gradient and the localization of PDGFR- $\beta$ on the cell membrane.

\section{3) Angiopoietin}

Angiopoietin/Tie2 signaling is important for vessel stabilization. Angiopoietin-1 causes tyrosine phosphorylation of the Tie2 receptor, thus resulting in downstream intracellular signaling. Angiopoietin-2 and its isoform act as antagonistic ligands for Tie2, and are considered natural Tie2 signaling antagonists.

The expression of angiopoietin-1 and angiopoietin-2 differs depending on the cell types in the microvessel wall. Dermal pericytes and endothelial cells exhibit a reciprocal expression of these molecules (Sundberg et al 2002). Angiopoietin-1 is expressed in the mesenchymal cells surrounding the endothelium, which can differentiate into pericytes (Patan 1998) and is produced by pericytes (Davis et al 1996; Sundberg 
et al 2002; Wakui et al 2006). Angiopoietin-2 is expressed in endothelial cells, whereas it may also be expressed in pericytes (Wakui et al 2006; Shim et al 2007). Angiopoietin-1 and angiopoietin-2 mediate opposite effects on Tie2 signaling via paracrine and autocrine mechanisms (Armulik et al2005).

The Tie2 receptor is predominantly expressed in endothelial cells (Dumont et al 1992; Sundberg et al 2002; Wakui et al 2006). Although the expression of Tie2 receptors on pericytes still remains controversial, Tie2 likely regulates these cells (Armulik et al 2005). In cultured retinal pericytes, the Tie2 receptor was functionally active (Cai et al 2008). In tumor neovascularization, Tie2 expression was observed in three distinct cell types: endothelial cells, proangiogenic cells of hematopoietic origin, and pericyte precursors of mesenchymal origin (De Palma et al 2005).

Pericyte-derived angiopoietin-1 binds to Tie2 receptors on endothelial cells and causes constitutive activation of the Tie2 receptor. Angiopoietin-1/Tie2 signaling promotes the survival of endothelial cells and maintains the endothelial cells in a quiescent resting state. In addition, angiopoietin-1/Tie2 induces the storage of dimeric angiopoietin-2 in endothelial cells. When the endothelial cells are activated, stored angiopoietin-2 is secreted and inhibits angiopoietin-1/Tie2 signaling. Chronic exposure of endothelial cells to angiopoietin-2 leads to apoptosis in the absence of cytokines (Sundberg et al2002; Armulik et al 2005; Fiedler and Augustin 2006).

Angiopoietin-1/Tie signaling contributes to vessel maturation and stabilization in association with the extracellular matrix and pericytes. Tie1-deficient mice exhibited leaky vessels with edema and hemorrhage (Sato et al 1995). Pericytes were scarce in mice lacking angiopoietin-1 or Tie2. The ultrastructural analysis showed that endothelial cells did not properly recruit or associate with pericytes in these mice (Suri et al 1996). Transgenic overexpression of angiopoietin-2 had similar effects to those of angiopoietin-1 and Tie2 deficiency (Maisonpierre et al 1997). Upregulation of angiopoietin-2 appears to be important for pericytes loss in diabetic retinopathy (Hammes et al 2004). Therefore, angiopoietin-1/Tie2 signaling is required for vessel stabilization and angiopoietin-2 antagonizes Tie2 signaling in endothelial cells, leading to vessel destabilization. Mutual interaction between angiopoietin-1 and angiopoietin-2 regulates angiogenic cascades triggered by angiogenic stimuli (Sundberg et al 2002; Armulik et al 2005; Fiedler and Augustin 2006).

It is not yet fully understood precisely how the angiopoietin-Tie signal is involved in the recruitment of pericytes. The angiopoietin/Tie2 signal may be coupled to PDGF/TGF- $\beta$-mediated chemotaxis, proliferation, and differentiation of smooth muscle cells (Vikkula et al 1996). It was suggested that Tie1 and Tie2 are 
required not for the recruitment of pericytes, but for the maintenance or survival of endothelial cells during late gestation (Puri et al 1999). Vasculogenesis proceeded normally in embryos lacking both Tie1 and Tie2. Mosaic analysis revealed that Tie1 and Tie2 were essential for the maintenance and survival of endothelial cells. Loss of Tie2 expression correlated with rapid endothelial cell apoptosis in hemorrhagic regions of the embryo (Jones et al 2001). Therefore, loss of pericyte recruitment caused by a loss of angiopoietin-1/Tie signaling may be due to endothelial cell apoptosis.

\section{4) Vascular endothelial growth factor}

VEGF is a powerful inducer of angiogenesis through endothelial cell activation. Pericytes secrete VEGF and modulate endothelial cell function (Hoeben et al 2004). Although VEGF stimulates the proliferation and migration of endothelial cells, the effects of VEGF on pericytes are less clear. VEGF and its receptor family members are expressed in both human dermal microvascular endothelial cells and bovine retinal pericytes, suggesting autocrine and paracrine mechanisms for regulating angiogenesis (Yonekura et al 1999).

VEGF likely regulates pericyte functions, because VEGF receptors are expressed in cultured retinal pericytes (Nomura et al 1995; Takagi et al 1996). In retinas from the neonatal rat, exogenous VEGF accelerated pericyte recruitment in the preformed endothelial network (Benjamin et al 1998). On the contrary, in tumors lacking myeloid-cell-derived VEGF-A, the vasculature was less torturous and had increased coverage of pericytes (Stockmann et al 2008). Blockade of VEGFR-2 increased the pericyte coverage of non-regressed brain tumor vessels via angiopoietin-1 upregulation, and degraded the basement membrane through matrix metalloprotease activation (Winkler et al 2004). Studies have recently demonstrated a novel VEGF mechanism for disruption of pericyte function and inhibition of vessel maturation. VEGF could induce the receptor complex consisting of VEGFR-2 and PDGFR- $\beta$. The activation of VEGFR-2 by VEGF suppressed PDGFR- $\beta$ signaling by assembling the receptor complex, which caused decreased pericyte coverage in vascular sprouts and vessel destabilization (Greenberg et al 2008). Therefore, VEGF can regulate angiogenesis by stimulating endothelial cells and by affecting pericyte recruitment.

\section{5) Regulator of G-protein signaing-5}

Regulator of G-protein signaling-5 (RGS-5) acts as a GTPase activating protein for Gia and Gqa. 
RGS-5 attenuates angiotensin II-, endothelin-1-, sphingosine-1-phosphate-, and PDGF-induced ERK-2 phosphorylation (Cho et al 2003). RGS-5 is important regulator of pericyte-endothelial interaction and the vascular maturation (Mitchell et al 2008). The expression pattern of RGS-5 is overlapped with that of PDGFR- $\beta$. Therefore, RGS- 5 is a potential angiogenic pericyte marker at sites of physiologic and pathologic angiogenesis (Berger et al 2005). RGS-5 was specifically induced in pericytes activated by an angiogenic switch. RGS-5 was upregulated when nascent vessel sprouts acquired pericyte coverage during neovascularization (Mitchell et al 2008). Therefore, RGS-5 can be used as a quantitative measure of pericyte coverage (Mitchell et al 2008). RGS-5 deficient mice were generated to determine this protein's function in tumor angiogenesis. However, pericyte coverage and association with endothelial cells were unaffected in RGS-5-deficient tumors. In mice lacking RGS-5, development of vasculature was normal with proper pericyte coverage (Nisancioglu et al 2008). On the contrary, RGS-5 deficient pericytes presented more mature phenotype than those in wild type. Therefore, the loss of RGS-5 may be associated with pericyte maturation, and thus result in the vascular normalization of tumor vessels (Hamzah et al 2008).

\section{6) Matrix metalloprotease}

Pericellular proteases are essential for angiogenesis. Matrix metalloproteases (MMP) belong to a family of zinc-dependent endopeptidases that digest specific extracellular matrix components and aid the activation of proteins such as other MMPs and growth factors. MMP-9 is necessary for the recruitment of pericytes to cover endothelial cells and stabilize newly-formed microvessels (van Hinsbergh et al 2006). A recent study showed that membrane-type MMP (MT-MMP) was important for tube formation of lumens by endothelial cells. Proteolysis by MT-MMP1 generated a vascular guidance tunnel for the migration of endothelial cells (Stratman et al 2009).

MMPs contribute to pericyte recruitment in various stages during angiogenesis (Chantrain et al 2006). Further study is required to determine the importance of proteases in pericyte-specific functions in angiogenesis. Similar to proteases, aminopeptidase A is present in activated pericytes in various pathological conditions associated with angiogenesis, whereas its expression was found to be low in the pericytes of quiescent vessels (Schlingemann et al 1996).

Endothelial cell-derived TIMP-2 and pericyte-derived TIMP-3 regulate capillary tube formation by inhibiting MT-MMP (Saunders et al 2006). Recruitment of pericytes into the endothelial cell-associated lumen 
induced expression of TIMP-3 in bovine retinal pericytes. Consequently, the protease inhibited endothelial tube formation and blocked endothelial cell movement (Saunders et al 2006; Stratman et al 2009). Therefore, the balance between MMPs and TIMPs appears to control the stabilization of the capillary lumen.

\section{7) Sphingosine-1-phosphate}

Sphingosine-1-phosphate (S1P) is a lysophospholipid mediator which is synthesized by membrane sphingolipid metabolism by sphingosine kinases (SPHKs) 1 and 2. S1P is produced by red blood cells, activated platelets, and endothelial cells and is secreted into the plasma. S1P binds its G-protein coupled receptors $\mathrm{S}_{1} \mathrm{P}_{1}, \mathrm{~S}_{1} \mathrm{P}_{2}$, and $\mathrm{S}_{1} \mathrm{P}_{3}$, and triggers diverse effects in cardiovascular systems (Takuwa et al 2008).

The knockout of the $\mathrm{S}_{1} \mathrm{P}_{1}$ receptor in mice blocked envelopment of nascent endothelial tubes with pericytes, which led to immature vessels (Allende and Proia 2002). Silencing $\mathrm{S}_{1} \mathrm{P}_{1}$ by local injection of $\mathrm{S}_{1} \mathrm{P}_{1}$ siRNA into tumors suppressed vascular stabilization and angiogenesis in the tumor (Chae et al 2004). The specific disruption of the $\mathrm{S}^{\mathrm{P}} \mathrm{P}_{1}$ gene in endothelial cells induced incomplete coverage with pericytes. The phenotype of the endothelium-specific disruption of $\mathrm{S}_{1} \mathrm{P}_{1}$ was similar to that in $\mathrm{S}_{1} \mathrm{P}_{1}$ receptor-deficient embryos. Therefore, pericyte coverage is regulated by $\mathrm{S}_{1} \mathrm{P}_{1}$ receptor signaling in endothelial cells (Allende et al 2003).

The mechanism for vascular stabilization by S1P/S1P 1 signaling is likely mediated by the activation of $\mathrm{N}$-cadherin in endothelial cells (Armulik et al 2005). Incomplete vascular maturation caused by pericyte deficiency in the $\mathrm{S} \mathrm{P}_{1}$ knockout mouse was due to an inability to activate the small GTPase, Rac (Liu et al 2000). The $S 1 \mathrm{P}_{1} / \mathrm{Gi} /$ Rac pathways in endothelial cells are required for proper $\mathrm{N}$-cadherin trafficking and for strengthening $\mathrm{N}$-cadherin-dependent cell-cell adhesion with pericytes in nascent blood vessels (Paik et al 2004). Cadherins are transmembrane proteins mediating cell-cell adhesion. $\mathrm{N}$-cadherin is present in adhesion junctions on endothelial cells and contributes to pericyte adhesion (Hirschi and D'Amore 1996; Gerhardt and Betsholtz 2003). N-cadherin is recruited not at endothelial cell-cell junctions but at sites where endothelial cells meet pericytes (Dejana 2004). In the embryonic chicken brain, blocking N-cadherin function impaired pericyte adhesion and increased pericyte recruitment. $\mathrm{N}$-cadherin mediated the adhesion between endothelial cells and pericytes and its disruption resulted in disturbed vascular morphogenesis in the brain (Gerhardt et al 2000). The lack of $\mathrm{N}$-cadherin in genetically manipulated ES cells led to impaired pericyte covering of endothelial outgrowths, although sprouting angiogenesis was unaltered (Tillet et al 2005). 
Therefore, S1P acts on $\mathrm{S}_{1} \mathrm{P}_{1}$ receptors on endothelial cells and strengthens the contact and coverage with pericytes through the activation of $\mathrm{N}$-cadherin expressed in endothelial cells.

\section{8) Notch}

The Notch signaling pathway is important for cell-cell communication. The Notch pathways are present both in the endothelium (Notch1, Notch4, Jagged1, DII-1 and -4, Hes1, Hey1, and Hey2) and in the surrounding pericytes, which also express Notch3 (Scehnet et al 2007).

In normal development and tumor angiogenesis, Notch signaling regulates blood vessel sprouting and branching (Noguera-Troise et al 2006; Gridley 2007; Sainson and Harris 2007; Dufraine et al 2008). Notch signaling is important for vessel stabilization and maturation. Heterotypic Notch signaling from endothelial cells to pericytes plays a role in pericyte coverage (Sainson and Harris 2008).

The Notch ligand DII4 is important for vessel maturation by affecting pericyte recruitment. The soluble form of the DII4 extracellular domain or the targeted allele deletion resulted in a marked reduction in pericyte recruitment (Scehnet et al 2007). Although Notch signal inhibition with a secreted soluble form of DII4 reduced pericyte activity, these cells were also absent in tumors expressing high DII4. Therefore, up- or downregulation of DII4 may cause similar responses (Li et al2007). A recent study has shown that endothelial Jagged1 increases Notch3 and Jagged1 expression through Notch3 on mural cells. Endothelial cells induces pericyte differentiation through the activation and induction of Notch3, thus indicating that the Notch3/Jagged1 interaction between cells may be important for the maintenance of the differentiated pericyte phenotype (Liu et al 2009).

\section{9) Endosialin}

Endosialin is a transmembrane glycoprotein originally identified as the antigen recognized by the FB5 monoclonal antibody. Endosialin is expressed in the tumor vasculature. Recent research has shown a strong expression of endosialin in pericytes during active angiogenesis, and endosialin was upregulated during embryonic and tumor development (Bagley et al 2008). Endosialin was not expressed in the normal human adult brain but was expressed in tumor vessel associated pericytes (MacFadyen et al 2007; Christian et al2008; Simonavicius et al 2008). Although the function of endosialin remains to be elucidated, this pericyte glycoprotein may be important in angiogenesis. 


\section{0) Integrin}

The adhesion between endothelial cells and pericytes is an indispensable step in angiogenesis. Moreover, cell-cell and cell-matrix adhesive interactions are required for angiogenesis. Among the proteins involved in these interactions, the integrins are important for this process and mediate pericyte attachment with endothelial cells and the extracellular matrix. Integrins are heteromeric transmembrane glycoprotein adhesion molecules and consist of two distinct chains, the $\alpha$ and $\beta$ subunits. Endothelial cells and pericytes express a subset of mammalian integrins including the fibronectin receptors $\alpha 4 \beta 1$ and $\alpha 5 \beta 1$; the collagen receptors $\alpha 1 \beta 1$ and $\alpha 2 \beta 1$; the laminin receptors $\alpha 3 \beta 1, \alpha 6 \beta 1$, and $\alpha 6 \beta 4$; and the osteopontin receptor $\alpha 9 \beta 1$. In addition, pericytes express the $\alpha 7 \beta 1$ (laminin receptor) and $\alpha 8 \beta 1$ (osteopontin receptor) integrins (Silva et al 2008).

Angiogenic sprouting and postangiogenic vessel survival in collagen were blocked by antibody against $\beta 1$ integrins. Therefore, $\beta 1$ integrins were considered to critically regulate the formation and survival of new vessels (Carnevale et al 2007). a4 $\beta 1$ integrin was expressed in endothelial cells in developing vessels. Conversely, proliferating pericytes expressed the a $4 \beta 1$ ligand vascular cell adhesion molecule (VCAM-1). The interaction between $\alpha 4 \beta 1$ integrin and VCAM-1 mediates endothelial cell and pericyte adhesion in developing vessels. Therefore, integrin $\alpha 4 \beta 1 / \mathrm{VCAM}-1$ signaling is critical for the correct interaction between endothelial cells and pericytes during neovascularization (Garmy-Susini et al 2005). Integrin-regulated angiogenesis appears to be mediated by pericyte function. Treatment of tumors with the av $\beta 3 / a v \beta 5$ integrin antagonist $S 247$ decreased pericyte coverage of vessels (Reinmuth et al 2003). In vitro and in vivo models demonstrated that the NG2 proteoglycan in pericytes interacts with $\alpha 3 \beta 1$ integrin in the endothelial cells. Galectin-3 enhances integrin-dependent signals by forming a multimolecular complex with a3ß1 integrin and NG2 proteoglycan. NG2 proteoglycan on the cell surface of pericytes stimulates the migration and morphogenesis of endothelial cells by activating transmembrane signaling through $\alpha 3 \beta 1$ integrin (Fukushi et al 2004). In the NG2 knock out mouse model, pericyte proliferation was reduced in the retina. Basic FGF-induced angiogenesis was also reduced in the NG2 null cornea (Ozerdem and Stallcup 2004). NG2 proteoglycan enhanced the proliferation of pericytes through activation of $\alpha 3 \beta 1$ integrin or the potentiation of growth factor signaling (Stallcup and Huang 2008).

The genetic ablation of integrin demonstrated the important roles of these molecules in angiogenesis 
and vascular development. Inactivation of the gene encoding integrin $\beta 1$ subunit in mice led to pericyte defects and postnatal lethality. Integrin $\beta 1$-deficient pericytes failed to extend long processes and lacked proper interactions with endothelial cells. As a result, mutant pericytes spread poorly, although they were present in larger numbers (Abraham et al 2008). In a4 integrin-deficient mouse embryos, pericytes failed to migrate and tended to cluster at angiogenic branch points. Cultured a4 integrin-null pericytes growing on fibronectin showed impaired migration and motility regulated by mechanical signals. Pericytes normally express $\alpha 4 \beta 1$ integrin, and $\alpha 4$ expression was localized predominantly on pericytes associated with angiogenic vessels. Therefore, $\alpha 4 \beta 1$ integrins are likely required for pericyte spread along angiogenic vessels (Grazioli et al 2006). The interaction between endothelial cells and pericytes upregulated integrins $\alpha 5 \beta 1, \alpha 3 \beta 1$, $\alpha 6 \beta 1$ and the fibronectin and laminins basement membrane proteins. Close contact between endothelial cells and pericytes induced basement membrane formation in vitro and in vivo (Stratman et al 2009). Accordingly, integrins and their receptors stabilize the vessels by mediating the interaction between pericytes and endothelial cells or the extracellular matrix.

\section{1) Ephrin}

The Eph receptor tyrosine kinases (RTKs) are activated in response to the binding of ephrin ligands to extracellular regions. Ephrin-Eph signaling is important for the interaction between endothelial cells and pericytes (Augustin and Reiss 2003; Kuijper et al 2007).

EphrinB2, a ligand for Eph receptor tyrosine kinases, was expressed in pericytes in the capillary as development proceeded (Gale et al 2001). The expression of Eph-ephrin molecules in mural cells was critical for assembly of the vessel walls during maturation (Kuijper et al 2007). The pericyte-specific inactivation of ephrinB2 clearly demonstrated the important role of this molecule in angiogenesis. EphrinB2-deficient pericytes showed insufficient contacts with endothelial cells and failed to envelope the endothelial monolayer. EphB-ephrinB2 interactions between endothelial cells and pericytes and between adjacent pericytes appear to control the directional migration of pericytes and the pericyte coating on maturing vessels (Foo et al 2006). EphrinB2 signaling contributes to proper assembly of endothelial cells and pericytes during postnatal angiogenic remodeling. This function requires bidirectional signaling through EphrinB2 and EphB surface-bound receptors through cell-to-cell contacts, and is dependent on Src tyrosine phosphorylation of the intracytoplasmic domain of ephrinB2 (Salvucci et al 2009). 
Eph-ephrin interactions may be linked to other angiogenic signaling pathways. In hepatic stellate cells, the resident pericytes in liver, ephrinB2 played a role in angiogenesis as a downstream effecter of PDGF signaling (Semela et al 2008). EphB4 decreased the permeability of the tumor vessels via angiopoietin-1/Tie2 signaling at the endothelium/pericyte interface. The activation of EphB4 reverse signaling via ephrinB2 increased the expression and phosphorylation of Tie2 in endothelial cells and angiopoietin-1 in pericytes (Erber et al 2006). Eph-ephrin signals act as a negative regulator for sprouting angiogenesis by pericyte coverage. In EphA2-deficient mice, the coverage of pericytes in the tracheal capillary was lower due to defective interactions between endothelial cells and pericytes, whereas the responses to inflammation were exaggerated (Okazaki et al 2009).

\section{2) Fibroblast growth factor}

FGF binds to heparan sulfate proteoglycans in the extracellular matrix, which is required for the activation of FGFR signaling. Consequently, FGF acts locally in a paracrine manner. FGF-2 is known as basic FGF. Angiogenesis was stimulated by conditioned medium from pericytes, and was inhibited by an antibody to basic FGF. Therefore, pericytes may stimulate angiogenesis via secretion of an FGF-like molecule (Watanabe et al 1997). A previous study suggested that FGF and PDGF have positive feedback effects on each other's signaling. Combination therapy with both PDGF-BB and FGF-2 markedly stimulated collateral arteriogenesis in the ischemic hind limb model (Cao et al 2003). It has been shown that FGF-2 upregulates PDGFR- $\alpha$ and PDGFR- $\beta$ in newly formed blood vessels (Cao et al 2003; Zhang et al 2009). FGF-2 enhances the expression of PDGFR- $\beta$ in cultured pericytes (Kano et a/2005). Moreover, it was shown that FGF-2 induced expression of PDGF- $\alpha$ and PDGFR- $\beta$ in endothelial cells, whereas PDGF-BB upregulated FGFR-1 in pericytes. PDGF-BB upregulated FGFR-1 promoter activity, which increased the responsiveness to FGF-2 (Nissen et al 2007). These results indicate that FGF-2 and PDGF-BB have synergistic effects on both signaling system by amplifying the mutual receptor expression. Both signals reciprocally increase their endothelial cell and pericyte responses, which results in disorganized neovascularization (Cao et al 2003; Nissen et al 2007).

\section{(3) Origin of pericytes}

Brain pericytes likely differentiate from the progenitor cells and proliferate during angiogenesis. The cells are generally accepted as being of mesodermal origin. It is assumed that pericytes are derived from the 
bone marrow (Figure 4). Bone marrow supplies perivascular progenitor cells, which can differentiate into pericytes (Lamagna and Bergers 2006). Another possibility is that pericyte progenitor cells originate from preexisting vasculature or from local tissues (Figure 4).

\section{1) Bone marrow}

Previous studies indicated that hematopoietic stem cells and bone marrow-derived mesenchymal stem cells were incorporated into the perivascular sites of the tumor vessels (Rajantie et al 2004; Bababeygy et al 2008; Bexell et al 2009). In the vessels of pancreatic islet tumors, PDGFR- $\beta+$ pericyte progenitor cells were recruited from the bone marrow to perivascular sites and differentiated into pericytes (Song et al 2005). In vessels of Ewing's tumors, specific subpopulations of bone marrow-derived progenitor cells differentiated into cells which expressed pericyte markers (Reddy et al 2008). During the angiogenesis in Ewing's tumors, the tumor microenvironment affected the differentiation pathway of bone marrow-derived cells (Reddy et al 2008). In neovascularization experiments using subcutaneous FGF-2-supplemented Matrigel plugs, over half of the pericytes in the vessel-like networks arose from bone marrow progenitors. The newly formed vessels contained pericytes of both bone marrow and non-bone marrow origin (Tigges et al 2008).

In brain ischemia, pericyte progenitor cells may be mobilized and recruited from bone marrow into ischemic areas. It was reported that in murine brain ischemia, bone marrow-derived cells were recruited from the peripheral blood and contributed to the remodeling and stabilization of newly formed blood vessels. The cells derived from bone marrow had the characteristics of pericytes and were positive for VEGF and TGF- $\beta$ (Kokovay et al 2006). More recently, novel mechanisms have been proposed concerning how pericytes are formed from bone marrow-derived cells. In stroke mouse models, fused cells of bone marrow-derived cell expressing specific markers for mature pericyte increased in the ischemic areas. These results indicated that pericytes were formed by cell fusion and the process participated in angiogenesis following stroke (Piquer-Gil et al 2009). Adult bone marrow is considered to be a rich reservoir of pericyte progenitor cells. Therefore, cells originating from the bone marrow likely play a role in angiogenesis induced by tumor and ischemia (Lamagna and Bergers 2006).

\section{2) Local environment}

Pericyte progenitors may also derive from the tumor microenvironment. A primary source of tumor 
pericytes was suggested to be a rare population of stroma-derived mesenchymal progenitors characterized by Tie2 expression (De Palma et al 2005). It was shown that the aorta contains immature mesenchymal cells capable of differentiating into pericytes. A population of immature mesenchymal cells in the postnatal rat aorta were transformed into pericytes when they were exposed to PDGF-BB or cocultured with endothelial cells (Howson et al 2005). A rat aorta model of angiogenesis also demonstrated that the aorta wall contains Tie2+ non-endothelial mesenchymal cells in the intimal/subintimal layers. These cells are a potential source of mural precursor cells and may contribute to angiogenesis in response to angiopoietin (lurlaro et al 2003). Thus, it remains to be determined whether pericyte progenitor cells are recruited from the bone marrow via peripheral circulation or if they originate from resident perivascular cells in the microenvironment.

\section{Blood brain barrier}

\section{(1) Neurovascular unit and anatomical structure}

The blood brain barrier (BBB) protects the brain from exposure to various toxic substances circulating in the blood (Smith and Gumbleton 2006; Cecchelli et al 2007; Bernacki et al 2008; Zlokovic 2008). The BBB is comprised of cerebral microvascular endothelial cells, pericytes, and astrocytes (Mathiisen et al 2010). These cells form a neurovascular unit together with neurons and extracellular matrix. Dysfunction of the neurovascular unit is one possible mechanism underlying disorders of the central nervous system (Hawkins and Davis 2005; Persidsky et al 2006).

Pericytes are important cellular constituent of the BBB. Recent studies have revealed that pericytes actively control vascular permeability at the capillary level in the brain. The close interaction between endothelial cells and pericytes is required for proper BBB function (Table 2). Lack of pericytes causes immature vessels and results in increased transendothelial permeability in the brain (Lindahl et al 1997; Hellstrom et al 2001). Accumulating evidence indicates that pericytes maintain the BBB (Balabanov and Dore-Duffy 1998; Thomas 1999; Lai and Kuo 2005; Persidsky et al 2006).

The anatomical structure of the capillary is stabilized by pericytes, since these cells encircle the capillary tube, which is composed of endothelial cells. Pericyte contraction mechanically tightens the junction between adjacent endothelial cells and thus protects it from overstretching. The decreased contractility of pericytes alters the physical barrier in the capillary by opening the inter-endothelial junction (Edelman et al 2006). In addition to anatomical structure, transport across the BBB is limited by physical (tight junction) and 
metabolic (enzymes and diverse transport systems) barriers (Persidsky et al 2006). Pericytes actively control these barriers by interacting with endothelial cells.

\section{(2) Mechanisms of BBB regulation}

An in vitro model which contains brain endothelial cells cocultured with brain pericytes and astrocytes can mimic BBB function. The in vitro BBB model has revealed that pericytes are required to maintain BBB function (Hori et al 2004; Dohgu et al 2005; Parkinson and Hacking 2005; Hartmann et al 2007; Nakagawa et al 2007; Kim et al 2008; Zozulya et al 2008; Cardoso et al 2010). Close contact between pericytes and endothelial cells is essential for barrier functions. In a triple coculture model, in which endothelial cells and pericytes were cultured on both sides of the filter membrane and astrocytes at the bottom of the culture dish, pericytes were necessary to maintain higher electrical resistance and lower permeability (Nakagawa et al 2007).

The barrier functions are maintained by BBB cellular junctions, BBB transport systems, and enzymatic BBB. Pericytes regulate endothelial cell tight junction formation, blood-brain barrier differentiation, and permeability through tight junction and transendothelial cell transport (Balabanov and Dore-Duffy 1998). Therefore, pericytes actively control the BBB by altering the function and expression of proteins associated with the BBB (Figure 5).

\section{1) BBB cellular junctions}

Tight junctions are facilitated by tight junction proteins, such as occludins, claudins, and other junctional proteins (junctional adhesion molecule-A), a cytoskeleton linking protein such as ZO-1 or actin, and adherens junctions (Hawkins and Davis 2005; Bernacki et al 2008; Zlokovic 2008). Proteins related to the tight junction are regulated by pericytes. Contact of endothelial cells with pericytes induced the expression of ZO-1 in developing retinal vessels (Kim et al 2009). In the presence of pericytes and astrocytes, expression levels of occludin, claudin-5, and ZO-1 at the borders of rat brain endothelial cells were enhanced (Nakagawa et al 2009). Moreover, tight junction molecules such as occludin, claudin-12, ZO-1, and ZO-2 were expressed in peripheral nerve pericytes. Therefore, pericytes themselves may facilitate transport through barriers in cooperation with endothelial cells (Shimizu et al 2008).

Extracellular matrices produced by pericytes improved brain endothelial barrier function as 
estimated by the electrical resistances (Hartmann et al 2007). An in vitro BBB model revealed that angiopoietin-1 secreted from pericytes induced occludin expression in brain capillary endothelial cells via Tie2 receptor activation (Hori et al 2004). Dexamethasone increased angiopoietin-1 but decreased VEGF expression in brain pericytes, which may underlie mechanisms of glucocorticoid-induced BBB stabilization (Kim et al 2008). Pericyte-conditioned medium increased occludin and ZO-1 expression under normoxia and partially reversed decreased expression of occludin under hypoxic conditions. Because an angiopoietin-1 neutralizing antibody inhibited these effects, tight junction proteins are considered to be regulated by pericyte-secreted angiopoietin-1 (Wang et al 2007). An in vitro BBB model with cocultured brain capillary endothelial cells and pericytes revealed that the pericytes upregulated BBB functions through continuous production of TGF- $\beta$. Therefore, pericyte-derived TGF- $\beta 1$ may be another regulator of BBB (Dohgu et al 2005). The level of TGF- $\beta 1$ is decreased by cyclosporin A in brain pericytes, suggesting that cyclosporin A-induced dysfunction of the BBB may be mediated by TGF- $\beta 1$ derived from pericytes (Takata et al 2007).

In addition to upregulation of tight junction proteins in endothelial cells, pericytes induce MMP secretion in endothelial cells, which contributes to hyperpermeability. Brain capillary endothelial cells co-cultured with pericytes resulted in an increased amount of endothelial MMP-9 and active MMPs (Zozulya et al 2008). Pericytes might trigger endothelial MMP production through cytokine mediators, including TGF, TNF, IL-6, and others (Virgintino et al 2007). MMPs can degrade basal lamina proteins such as fibronectin, laminin, and heparan sulfate (Zlokovic 2006). Therefore, secretion of MMP by pericytes contributes to the breakdown of BBB.

\section{2) BBB transport systems}

ATP-binding cassette transporters may be functionally regulated by pericytes. Diffusible factors from pericytes were sufficient to induce MRP6 expression in brain capillary endothelial cells (Berezowski et al 2004). In a co-culture model, brain pericytes upregulated barrier function and P-glycoprotein functional activity of brain endothelial cells via TGF- $\beta 1$ signaling (Takata et al 2007). Transporters may also be expressed in peripheral nerve pericytes. The barrier-related transporters ABCG2, P-glycoprotein, MRP-1, and Glut-1 were detected in pericytes (Shimizu et al 2008). Immunogold cytochemistry electronmicroscopic studies revealed that P-glycoprotein was expressed at the luminal and abluminal membranes of pericytes in rat and human brains (Bendayan et al 2006). 


\section{Macrophage activity}

Early investigators observed and discriminated between granular and agranular pericytes. Brain pericytes have cytoplasmic lysosomes, which account for their granular appearance. Macrophage components were shown to be present in brain pericytes. They had Fc receptors, exhibited antibody-dependent phagocytosis, and acted as antigen-presenting cells (Thomas 1999; Guillemin and Brew 2004). Moreover, it has been reported that these cells express macrophage scavenger receptors and likely act as scavenger cells (Balabanov and Dore-Duffy 1998; Thomas 1999). Pericytes can uptake soluble and small molecules from the blood or brain parenchyma through interstitial fluid. These cells transport materials by infoldings of the plasma membrane, endocytosis through pinocytosis or phagocytosis, and through receptor-mediated endocytosis (Balabanov and Dore-Duffy 1998; Lai and Kuo 2005). Therefore, brain pericytes may represent the first line of immunologic defense of the brain (Balabanov et al 1999; Guillemin and Brew 2004).

Pericytes migrating into the brain parenchyma may act in a similar manner to brain macrophages, such as macrophage infiltrating into the brain, perivascular macrophage, and microglia. The pericytes may be another myeloid cell type located adjacent to but distinct from the perivascular macrophage (Guillemin and Brew 2004). Brain pericytes act in the neuroimmune systems as brain macrophages in cooperation with various types of brain macrophages. Although the functional and cellular differences among brain macrophages are still poorly understood, pericytes may modulate immune system function by controlling NK cells, T cells, and B cells. Further study will define the immunomodulatory roles of pericytes in the brain.

\section{Pluripotent activity}

Pericytes are plastic and multipotent. Pericytes isolated from various tissues have the ability to differentiate into other mesenchymal cell types, such as smooth muscle cells, fibroblasts, adipocytes, chondrocytes, and osteocytes (Figure 5). A recent study has shown that mesenchymal stem cells reside in the perivascular position and have characteristics of pericytes (da Silva Meirelles et al 2008; Caplan 2009). Moreover, pericytes have been suggested to affiliate with mesenchymal stem cells (Caplan 2008; Crisan et al 2008). Although it is still unclear whether pericytes associate with mesenchymal stem cells, the perivascular zone may be the mesenchymal stem cell niche in vivo. 


\section{(1) Brain}

Brain microvascular pericytes appear to be a source of adult multipotent progenitor cells, because they express markers characteristic of pericytes, neurons, and glial cells during culture with bFGF-containing media without serum. These data suggest that brain microvascular pericytes have neural stem cell capabilities (Dore-Duffy et al 2006). Perivascular cells isolated from mouse meninges not only expressed pericyte-specific markers but also stem cell markers. The cells displayed phenotypic characteristics of pericytes with a distinct developmental potential (Brachvogel et al 2005; Brachvogel et al 2007). Hematopoietic stem cells expressed pericyte progenitor markers as well as pericyte markers (Bababeygy et al 2008). Therefore, brain pericytes are able to differentiate into progenitor and mature cells with distinct phenotypes. The microvasculature may serve as a pool of mesenchymal stem cells in the brain.

\section{(2) Other organs}

Adipose-derived stromal cells located at the perivascular position express mesenchymal, pericytic, and smooth muscle markers. Although they exhibited pericyte properties, they were pluripotent and capable of differentiating into distinct lineages (Traktuev et al 2008). Pericytes were able to differentiate along the adipocytic and chondrocytic lineages in vitro and in vivo (Farrington-Rock et al 2004). PDGFR- $\beta+$ stromal vascular cells in adipose tissue had adipogenic potential, but PDGFR- $\beta+$ cells isolated from other organs did not display this adipogenic potential. The microvasculature in the adipose tissue may function as a niche for adipocytes (Tang et al 2008). Pericytes from microvascular walls in postnatal skeletal muscle were able to regenerate skeletal muscle. Therefore, pericytes represent myogenic precursors in human skeletal muscle (Dellavalle et al 2007; Morgan and Muntoni 2007). Skin pericytes have been shown to act as mesenchymal cells, and exhibited the capability to differentiate into different lineages, such as bone, fat, and cartilage. In addition, skin pericytes modified the microenvironment and promoted skin regeneration independent of angiogenesis (Paquet-Fifield et al 2009). Pericytes in various tissues may have mesenchymal stem cell potential (Caplan 2008; Crisan et al 2008).

\section{Conclusion}

Brain pericytes are considered to play a pivotal role in the maintenance of the brain function. 
Malfunction of these cells may underlie the pathogenesis of CNS diseases through the dysregulation of microcirculation, angiogensis, blood brain barrier and neurogenesis.

\section{Figure Legends}

Figure 1. Pericytes control capillary flow.

Diameters of the capillary lumen are altered by contracture of surrounding pericytes. Capillary flow is controlled by dilatation (A) or contraction (B) of pericytes in response to physiological (e.g. neural activity) as well as pathological conditions (e.g. acidosis and reactive oxygen species) in the microenvironment.

Figure 2. Pericytes stabilize newly formed vessels.

In stabilized vessels, pericytes are tightly attached to the endothelial cells with interjacent basement membrane. The stabilized capillaries function as mature vessels and sustain the homeostasis between the blood and the parenchyma (A). When stimulated, the pericytes are detached from the perivascular position and capillary vessels are unstabilized (B). After pericyte detachment, endothelial cells are activated and the basement membrane and ECM are degraded. The stimulated endothelial cells migrate and proliferate into the ECM. The stimulated endothelial cells develop immature lumens, which hyperdilate and exhibit hyperpermeability. Newly formed vessels are restabilized by pericytes.

Figure 3. Angiogenic signaling in triangle of pericytes, endothelial cells, and extracellular matrix

Angiogenesis is finely modulated by the interaction between pericytes and endothelial cells. Pericytes and endothelial cells secrete a variety of angiogenic factors. These signaling molecules act on adjacent homoand heterotypic cells via their specific receptors in an autocrine or paracrine manner (e.g. TGF- $\beta$ /TGF- $\beta$ RII-ALK1， ALK5, PDGF-B/PDGFR- $\beta, \quad$ angiopoietin-1,-2/Tie2, VEGF/VEGFR-2, sphyngosine-1-phosphate/S1P 1 , FGF-2/FGFR). During angiogenesis, regulator of G-protein signaling-5 (RGS-5) may contribute to the signal transduction by regulating the activity of G proteins. Direct cell-cell communication through cell surface proteins or cell-ECM interactions are also involved in regulation (e.g. integrin, endosialin, $\mathrm{N}$-cadherin, Notch). Matrix metalloprotease (MMP) degrades proteins in the extracellular matrix and modulates the interaction of the cells by its degradation. The relationship between pericytes, endothelial cells, and extracellular matrix proteins controls angiogenesis and consequently affects tissue 
regeneration.

Figure 4. Pericytes in blood brain barrier

Pericytes directly or indirectly control the BBB. They actively regulate the expression of tight junctions (claudin and occludin) or zonula occludens in endothelial cells and strengthen barrier functions. They express BBB components, BBB transporters (ABC transporters), solute carriers (GLUT1 and SGUT), and BBB ectoenzymes. In addition, pericytes have phagocytotic activity and remove macromolecules in the perivascular space.

Figure 5. Origin and pluripotential of pericytes

Pericytes may be recruited from bone marrow-derived cells through the peripheral circulation. In addition, the cells may originate from the local environment. Pericytes appear to possess pluripotent activity and can differentiate into different lineages. 


\section{Acknowledgement}

This study was partially supported by Coordination, Support and Training Program for Translational Research and Grant-in-Aid for Scientific Research (C 19590992, C 22590937) from The Japanese Ministry of Education, Culture, Sports, Science and Technology. We are grateful to Dr. Masanori Wakisaka for his helpful comments. 


\section{References}

Abraham S, Kogata N, Fassler R, Adams RH (2008). Integrin $\beta 1$ subunit controls mural cell adhesion, spreading, and blood vessel wall stability. Circ Res 102: 562-70.

Abramsson A, Kurup S, Busse M, Yamada S, Lindblom P, Schallmeiner E, Stenzel D, Sauvaget D, Ledin J, Ringvall M, Landegren U, Kjellen L, Bondjers G, Li JP, Lindahl U, Spillmann D, Betsholtz C, Gerhardt H (2007). Defective N-sulfation of heparan sulfate proteoglycans limits PDGF-BB binding and pericyte recruitment in vascular development. Genes Dev 21: 316-31.

Allende ML, Proia RL (2002). Sphingosine-1-phosphate receptors and the development of the vascular system. Biochim Biophys Acta 1582: 222-7.

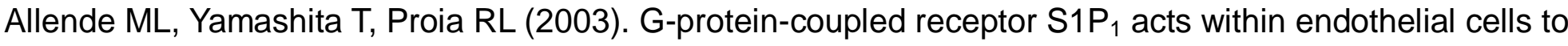
regulate vascular maturation. Blood 102: 3665-7.

Allt G, Lawrenson JG (2001). Pericytes: cell biology and pathology. Cells Tissues Organs 169: 1-11.

Andrae J, Gallini R, Betsholtz C (2008). Role of platelet-derived growth factors in physiology and medicine. Genes Dev 22: 1276-312.

Antonelli-Orlidge A, Saunders KB, Smith SR, D'Amore PA (1989). An activated form of transforming growth factor $\beta$ is produced by cocultures of endothelial cells and pericytes. Proc Natl Acad Sci U S A 86: 4544-8.

Armulik A, Abramsson A, Betsholtz C (2005). Endothelial/pericyte interactions. Circ Res 97: 512-23.

Augustin HG, Reiss Y (2003). EphB receptors and ephrinB ligands: regulators of vascular assembly and homeostasis. Cell Tissue Res 314: 25-31.

Bababeygy SR, Cheshier SH, Hou LC, Higgins DM, Weissman IL, Tse VC (2008). Hematopoietic stem cell-derived pericytic cells in brain tumor angio-architecture. Stem Cells Dev 17: 11-8.

Bagley RG, Honma N, Weber W, Boutin P, Rouleau C, Shankara S, Kataoka S, Ishida I, Roberts BL, Teicher BA (2008). Endosialin/TEM 1/CD248 is a pericyte marker of embryonic and tumor neovascularization. Microvasc Res 76: 180-8.

Balabanov R, Beaumont T, Dore-Duffy P (1999). Role of central nervous system microvascular pericytes in activation of antigen-primed splenic T-lymphocytes. J Neurosci Res 55: 578-87.

Balabanov R, Dore-Duffy P (1998). Role of the CNS microvascular pericyte in the blood-brain barrier. $J$ Neurosci Res 53: 637-44. 
Ball SG, Shuttleworth CA, Kielty CM (2007). Mesenchymal stem cells and neovascularization: role of platelet-derived growth factor receptors. J Cell Mol Med 11: 1012-30.

Bandopadhyay R, Orte C, Lawrenson JG, Reid AR, De Silva S, Allt G (2001). Contractile proteins in pericytes at the blood-brain and blood-retinal barriers. $J$ Neurocyto/ 30: 35-44.

Beck L, Jr., D'Amore PA (1997). Vascular development: cellular and molecular regulation. FASEB J 11: 365-73.

Bendayan R, Ronaldson PT, Gingras D, Bendayan M (2006). In situ localization of P-glycoprotein (ABCB1) in human and rat brain. J Histochem Cytochem 54: 1159-67.

Benjamin LE, Hemo I, Keshet E (1998). A plasticity window for blood vessel remodelling is defined by pericyte coverage of the preformed endothelial network and is regulated by PDGF-B and VEGF. Development 125: $1591-8$.

Berezowski V, Landry C, Dehouck MP, Cecchelli R, Fenart L (2004). Contribution of glial cells and pericytes to the mRNA profiles of P-glycoprotein and multidrug resistance-associated proteins in an in vitro model of the blood-brain barrier. Brain Res 1018: 1-9.

Berger M, Bergers G, Arnold B, Hammerling GJ, Ganss R (2005). Regulator of G-protein signaling-5 induction in pericytes coincides with active vessel remodeling during neovascularization. Blood 105: 1094-101.

Bergers G, Song S (2005). The role of pericytes in blood-vessel formation and maintenance. Neuro Oncol 7: $452-64$.

Bernacki J, Dobrowolska A, Nierwinska K, Malecki A (2008). Physiology and pharmacological role of the blood-brain barrier. Pharmacol Rep 60: 600-22.

Bertolino P, Deckers M, Lebrin F, ten Dijke P (2005). Transforming growth factor- $\beta$ signal transduction in angiogenesis and vascular disorders. Chest 128: 585S-590S.

Bexell D, Gunnarsson S, Tormin A, Darabi A, Gisselsson D, Roybon L, Scheding S, Bengzon J (2009). Bone marrow multipotent mesenchymal stroma cells act as pericyte-like migratory vehicles in experimental gliomas. Mol Ther 17: 183-90.

Boado RJ, Pardridge WM (1994). Differential expression of $\alpha$-actin mRNA and immunoreactive protein in brain microvascular pericytes and smooth muscle cells. J Neurosci Res 39: 430-5.

Bondjers C, He L, Takemoto M, Norlin J, Asker N, Hellstrom M, Lindahl P, Betsholtz C (2006). Microarray analysis of blood microvessels from PDGF-B and PDGF-R $\beta$ mutant mice identifies novel markers for 
brain pericytes. FASEB J 20: 1703-5.

Brachvogel B, Moch H, Pausch F, Schlotzer-Schrehardt U, Hofmann C, Hallmann R, von der Mark K, Winkler T, Poschl E (2005). Perivascular cells expressing annexin A5 define a novel mesenchymal stem cell-like population with the capacity to differentiate into multiple mesenchymal lineages. Development 132: $2657-68$.

Brachvogel B, Pausch F, Farlie P, Gaipl U, Etich J, Zhou Z, Cameron T, von der Mark K, Bateman JF, Poschl E (2007). Isolated Anxa5+/Sca-1+ perivascular cells from mouse meningeal vasculature retain their perivascular phenotype in vitro and in vivo. Exp Cell Res 313: 2730-43.

Braun A, Xu H, Hu F, Kocherlakota P, Siegel D, Chander P, Ungvari Z, Csiszar A, Nedergaard M, Ballabh P (2007). Paucity of pericytes in germinal matrix vasculature of premature infants. J Neurosci 27: 12012-24.

Cai J, Kehoe O, Smith GM, Hykin P, Boulton ME (2008). The angiopoietin/Tie-2 system regulates pericyte survival and recruitment in diabetic retinopathy. Invest Ophthalmol Vis Sci 49: 2163-71.

Cao R, Brakenhielm E, Pawliuk R, Wariaro D, Post MJ, Wahlberg E, Leboulch P, Cao Y (2003). Angiogenic synergism, vascular stability and improvement of hind-limb ischemia by a combination of PDGF-BB and FGF-2. Nat Med 9: 604-13.

Caplan Al (2008). All MSCs are pericytes? Cell Stem Cell 3: 229-30.

Caplan Al (2009). Why are MSCs therapeutic? New data: new insight. J Pathol 217: 318-24.

Cardoso FL, Brites D, Brito MA (2010). Looking at the blood-brain barrier: Molecular anatomy and possible investigation approaches. Brain Res Rev 64: 328-63.

Carnevale E, Fogel E, Aplin AC, Gelati M, Howson KM, Zhu WH, Nicosia RF (2007). Regulation of postangiogenic neovessel survival by $\beta 1$ and $\beta 3$ integrins in collagen and fibrin matrices. $J$ Vasc Res 44: $40-50$.

Carvalho RL, Jonker L, Goumans MJ, Larsson J, Bouwman P, Karlsson S, Dijke PT, Arthur HM, Mummery CL (2004). Defective paracrine signalling by TGF $\beta$ in yolk sac vasculature of endoglin mutant mice: a paradigm for hereditary haemorrhagic telangiectasia. Development 131: 6237-47.

Cecchelli R, Berezowski V, Lundquist S, Culot M, Renftel M, Dehouck MP, Fenart L (2007). Modelling of the blood-brain barrier in drug discovery and development. Nat Rev Drug Discov 6: 650-61.

Chae SS, Paik JH, Furneaux H, Hla T (2004). Requirement for sphingosine 1-phosphate receptor-1 in tumor 
angiogenesis demonstrated by in vivo RNA interference. J Clin Invest 114: 1082-9.

Chakravarthy U, Gardiner TA, Anderson P, Archer DB, Trimble ER (1992). The effect of endothelin 1 on the retinal microvascular pericyte. Microvasc Res 43: 241-54.

Chantrain CF, Henriet P, Jodele S, Emonard H, Feron O, Courtoy PJ, DeClerck YA, Marbaix E (2006). Mechanisms of pericyte recruitment in tumour angiogenesis: a new role for metalloproteinases. Eur $J$ Cancer 42: 310-8.

Cho H, Kozasa T, Bondjers C, Betsholtz C, Kehrl JH (2003). Pericyte-specific expression of RGS5: implications for PDGF and EDG receptor signaling during vascular maturation. FASEB J 17: 440-2.

Christian S, Winkler R, Helfrich I, Boos AM, Besemfelder E, Schadendorf D, Augustin HG (2008). Endosialin (Tem1) is a marker of tumor-associated myofibroblasts and tumor vessel-associated mural cells. Am J Pathol 172: 486-94.

Crisan M, Yap S, Casteilla L, Chen CW, Corselli M, Park TS, Andriolo G, Sun B, Zheng B, Zhang L, Norotte C, Teng PN, Traas J, Schugar R, Deasy BM, Badylak S, Buhring HJ, Giacobino JP, Lazzari L, Huard J, Peault B (2008). A perivascular origin for mesenchymal stem cells in multiple human organs. Cell Stem Cell 3: 301-13.

da Silva Meirelles L, Caplan AI, Nardi NB (2008). In search of the in vivo identity of mesenchymal stem cells. Stem Cells 26: 2287-99.

Darland DC, D'Amore PA (2001). TGF $\beta$ is required for the formation of capillary-like structures in three-dimensional cocultures of 10T1/2 and endothelial cells. Angiogenesis 4: 11-20.

Davis S, Aldrich TH, Jones PF, Acheson A, Compton DL, Jain V, Ryan TE, Bruno J, Radziejewski C, Maisonpierre PC, Yancopoulos GD (1996). Isolation of angiopoietin-1, a ligand for the TIE2 receptor, by secretion-trap expression cloning. Cell 87: 1161-9.

De Palma M, Venneri MA, Galli R, Sergi Sergi L, Politi LS, Sampaolesi M, Naldini L (2005). Tie2 identifies a hematopoietic lineage of proangiogenic monocytes required for tumor vessel formation and a mesenchymal population of pericyte progenitors. Cancer Cell 8: 211-26.

Dejana E (2004). Endothelial cell-cell junctions: happy together. Nat Rev Mol Cell Bio/ 5: 261-70.

Dellavalle A, Sampaolesi M, Tonlorenzi R, Tagliafico E, Sacchetti B, Perani L, Innocenzi A, Galvez BG, Messina G, Morosetti R, Li S, Belicchi M, Peretti G, Chamberlain JS, Wright WE, Torrente Y, Ferrari S, Bianco P, Cossu G (2007). Pericytes of human skeletal muscle are myogenic precursors distinct from 
satellite cells. Nat Cell Bio/ 9: 255-67.

Dewever J, Frerart F, Bouzin C, Baudelet C, Ansiaux R, Sonveaux P, Gallez B, Dessy C, Feron O (2007). Caveolin-1 is critical for the maturation of tumor blood vessels through the regulation of both endothelial tube formation and mural cell recruitment. Am J Pathol 171: 1619-28.

Ding R, Darland DC, Parmacek MS, D'Amore PA (2004). Endothelial-mesenchymal interactions in vitro reveal molecular mechanisms of smooth muscle/pericyte differentiation. Stem Cells Dev 13: 509-20.

Dohgu S, Takata F, Yamauchi A, Nakagawa S, Egawa T, Naito M, Tsuruo T, Sawada Y, Niwa M, Kataoka Y (2005). Brain pericytes contribute to the induction and up-regulation of blood-brain barrier functions through transforming growth factor- $\beta$ production. Brain Res 1038: 208-15.

Dore-Duffy P (2008). Pericytes: pluripotent cells of the blood brain barrier. Curr Pharm Des 14: 1581-93.

Dore-Duffy P, Katychev A, Wang X, Van Buren E (2006). CNS microvascular pericytes exhibit multipotential stem cell activity. J Cereb Blood Flow Metab 26: 613-24.

Dufraine J, Funahashi Y, Kitajewski J (2008). Notch signaling regulates tumor angiogenesis by diverse mechanisms. Oncogene 27: 5132-7.

Dumont DJ, Yamaguchi TP, Conlon RA, Rossant J, Breitman ML (1992). tek, a novel tyrosine kinase gene located on mouse chromosome 4, is expressed in endothelial cells and their presumptive precursors. Oncogene 7: 1471-80.

Edelman DA, Jiang Y, Tyburski J, Wilson RF, Steffes C (2006). Pericytes and their role in microvasculature homeostasis. J Surg Res 135: 305-11.

Enge M, Bjarnegard M, Gerhardt H, Gustafsson E, Kalen M, Asker N, Hammes HP, Shani M, Fassler R, Betsholtz C (2002). Endothelium-specific platelet-derived growth factor-B ablation mimics diabetic retinopathy. $E M B O \mathrm{~J} 21: 4307-16$.

Erber R, Eichelsbacher U, Powajbo V, Korn T, Djonov V, Lin J, Hammes HP, Grobholz R, Ullrich A, Vajkoczy P (2006). EphB4 controls blood vascular morphogenesis during postnatal angiogenesis. EMBO J 25: 628-41.

Farrington-Rock C, Crofts NJ, Doherty MJ, Ashton BA, Griffin-Jones C, Canfield AE (2004). Chondrogenic and adipogenic potential of microvascular pericytes. Circulation 110: 2226-32.

Fernandez LA, Sanz-Rodriguez F, Blanco FJ, Bernabeu C, Botella LM (2006). Hereditary hemorrhagic telangiectasia, a vascular dysplasia affecting the TGF- $\beta$ signaling pathway. Clin Med Res 4: 66-78. 
Ferrari-Dileo G, Davis EB, Anderson DR (1996). Glaucoma, capillaries and pericytes. 3. Peptide hormone binding and influence on pericytes. Ophthalmologica 210: 269-75.

Fiedler U, Augustin HG (2006). Angiopoietins: a link between angiogenesis and inflammation. Trends Immunol 27: 552-8.

Foo SS, Turner CJ, Adams S, Compagni A, Aubyn D, Kogata N, Lindblom P, Shani M, Zicha D, Adams RH (2006). Ephrin-B2 controls cell motility and adhesion during blood-vessel-wall assembly. Cell 124: 161-73.

Frank RN, Dutta S, Mancini MA (1987). Pericyte coverage is greater in the retinal than in the cerebral capillaries of the rat. Invest Ophthalmol Vis Sci 28: 1086-91.

Fukushi J, Makagiansar IT, Stallcup WB (2004). NG2 proteoglycan promotes endothelial cell motility and angiogenesis via engagement of galectin-3 and a3ß1 integrin. Mol Biol Cell 15: 3580-90.

Gaengel K, Genove G, Armulik A, Betsholtz C (2009). Endothelial-mural cell signaling in vascular development and angiogenesis. Arterioscler Thromb Vasc Biol 29: 630-8.

Gale NW, Baluk P, Pan L, Kwan M, Holash J, DeChiara TM, McDonald DM, Yancopoulos GD (2001). Ephrin-B2 selectively marks arterial vessels and neovascularization sites in the adult, with expression in both endothelial and smooth-muscle cells. Dev Biol 230: 151-60.

Garmy-Susini B, Jin H, Zhu Y, Sung RJ, Hwang R, Varner J (2005). Integrin a4ß1-VCAM-1-mediated adhesion between endothelial and mural cells is required for blood vessel maturation. J Clin Invest 115: $1542-51$.

Gerhardt H, Betsholtz C (2003). Endothelial-pericyte interactions in angiogenesis. Cell Tissue Res 314: 15-23.

Gerhardt H, Wolburg H, Redies C (2000). N-cadherin mediates pericytic-endothelial interaction during brain angiogenesis in the chicken. Dev Dyn 218: 472-9.

Goumans MJ, Liu Z, ten Dijke P (2009). TGF- $\beta$ signaling in vascular biology and dysfunction. Cell Res 19: $116-27$.

Grazioli A, Alves CS, Konstantopoulos K, Yang JT (2006). Defective blood vessel development and pericyte/pvSMC distribution in a 4 integrin-deficient mouse embryos. Dev Biol 293: 165-77.

Greenberg JI, Shields DJ, Barillas SG, Acevedo LM, Murphy E, Huang J, Scheppke L, Stockmann C, Johnson RS, Angle N, Cheresh DA (2008). A role for VEGF as a negative regulator of pericyte function and 
vessel maturation. Nature 456: 809-13.

Gridley T (2007). Notch signaling in vascular development and physiology. Development 134: 2709-18.

Guillemin GJ, Brew BJ (2004). Microglia, macrophages, perivascular macrophages, and pericytes: a review of function and identification. J Leukoc Biol 75: 388-97.

Hall AP (2006). Review of the pericyte during angiogenesis and its role in cancer and diabetic retinopathy. Toxicol Pathol 34: 763-75.

Hammes HP, Lin J, Wagner P, Feng Y, Vom Hagen F, Krzizok T, Renner O, Breier G, Brownlee M, Deutsch U (2004). Angiopoietin-2 causes pericyte dropout in the normal retina: evidence for involvement in diabetic retinopathy. Diabetes 53: 1104-10.

Hamzah J, Jugold M, Kiessling F, Rigby P, Manzur M, Marti HH, Rabie T, Kaden S, Grone HJ, Hammerling GJ, Arnold B, Ganss R (2008). Vascular normalization in RGS5-deficient tumours promotes immune destruction. Nature 453: 410-4.

Hartmann C, Zozulya A, Wegener J, Galla HJ (2007). The impact of glia-derived extracellular matrices on the barrier function of cerebral endothelial cells: an in vitro study. Exp Cell Res 313: 1318-25.

Hawkins BT, Davis TP (2005). The blood-brain barrier/neurovascular unit in health and disease. Pharmacol Rev 57: 173-85.

Hellstrom M, Gerhardt H, Kalen M, Li X, Eriksson U, Wolburg H, Betsholtz C (2001). Lack of pericytes leads to endothelial hyperplasia and abnormal vascular morphogenesis. J Cell Biol 153: 543-53.

Hellstrom M, Kalen M, Lindahl P, Abramsson A, Betsholtz C (1999). Role of PDGF-B and PDGFR- $\beta$ in recruitment of vascular smooth muscle cells and pericytes during embryonic blood vessel formation in the mouse. Development 126: 3047-55.

Hirase H, Creso J, Singleton M, Bartho P, Buzsaki G (2004). Two-photon imaging of brain pericytes in vivo using dextran-conjugated dyes. Glia 46: 95-100.

Hirschi KK, Burt JM, Hirschi KD, Dai C (2003). Gap junction communication mediates transforming growth factor- $\beta$ activation and endothelial-induced mural cell differentiation. Circ Res 93: 429-37. Hirschi KK, D'Amore PA (1996). Pericytes in the microvasculature. Cardiovasc Res 32: 687-98. Hirschi KK, Rohovsky SA, Beck LH, Smith SR, D'Amore PA (1999). Endothelial cells modulate the proliferation of mural cell precursors via platelet-derived growth factor-BB and heterotypic cell contact. Circ Res 84: 298-305. 
Hirschi KK, Rohovsky SA, D'Amore PA (1998). PDGF, TGF- $\beta$, and heterotypic cell-cell interactions mediate endothelial cell-induced recruitment of $10 T 1 / 2$ cells and their differentiation to a smooth muscle fate. $J$ Cell Biol 141: 805-14.

Hoeben A, Landuyt B, Highley MS, Wildiers H, Van Oosterom AT, De Bruijn EA (2004). Vascular endothelial growth factor and angiogenesis. Pharmacol Rev 56: 549-80.

Hori S, Ohtsuki S, Hosoya K, Nakashima E, Terasaki T (2004). A pericyte-derived angiopoietin-1 multimeric complex induces occludin gene expression in brain capillary endothelial cells through Tie-2 activation in vitro. J Neurochem 89: 503-13.

Howson KM, Aplin AC, Gelati M, Alessandri G, Parati EA, Nicosia RF (2005). The postnatal rat aorta contains pericyte progenitor cells that form spheroidal colonies in suspension culture. Am J Physiol Cell Physiol 289: C1396-407.

lurlaro M, Scatena M, Zhu WH, Fogel E, Wieting SL, Nicosia RF (2003). Rat aorta-derived mural precursor cells express the Tie2 receptor and respond directly to stimulation by angiopoietins. J Cell Sci 116: $3635-43$.

Jariyapongskul A, Nakano A, Yamaguchi S, Nageswari K, Niimi H (2003). Maturity of pericytes in cerebral neocapillaries induced by growth factors: fluorescence immuno-histochemical analysis using confocal laser microscopy. Clin Hemorheol Microcirc 29: 417-21.

Jones N, Voskas D, Master Z, Sarao R, Jones J, Dumont DJ (2001). Rescue of the early vascular defects in Tek/Tie2 null mice reveals an essential survival function. EMBO Rep 2: 438-45.

Kamouchi M, Kitazono T, Ago T, Wakisaka M, Kuroda J, Nakamura K, Hagiwara N, Ooboshi H, Ibayashi S, lida M (2007). Hydrogen peroxide-induced $\mathrm{Ca}^{2+}$ responses in CNS pericytes. Neurosci Lett 416: 12-6. Kamouchi M, Kitazono T, Ago T, Wakisaka M, Ooboshi H, Ibayashi S, lida M (2004). Calcium influx pathways in rat CNS pericytes. Brain Res Mol Brain Res 126: 114-20.

Kano MR, Morishita Y, Iwata C, Iwasaka S, Watabe T, Ouchi Y, Miyazono K, Miyazawa K (2005). VEGF-A and FGF-2 synergistically promote neoangiogenesis through enhancement of endogenous PDGF-B-PDGFRß signaling. J Cell Sci 118: 3759-68.

Kim H, Lee JM, Park JS, Jo SA, Kim YO, Kim CW, Jo I (2008). Dexamethasone coordinately regulates angiopoietin-1 and VEGF: a mechanism of glucocorticoid-induced stabilization of blood-brain barrier. Biochem Biophys Res Commun 372: 243-8. 
Kim JH, Yu YS, Kim DH, Kim KW (2009). Recruitment of pericytes and astrocytes is closely related to the formation of tight junction in developing retinal vessels. J Neurosci Res 87: 653-9.

Kokovay E, Li L, Cunningham LA (2006). Angiogenic recruitment of pericytes from bone marrow after stroke. J Cereb Blood Flow Metab 26: 545-55.

Krueger M, Bechmann I (2010). CNS pericytes: concepts, misconceptions, and a way out. Glia 58: 1-10. Kuijper S, Turner CJ, Adams RH (2007). Regulation of angiogenesis by Eph-ephrin interactions. Trends Cardiovasc Med 17: 145-51.

Kunz J, Krause D, Kremer M, Dermietzel R (1994). The 140-kDa protein of blood-brain barrier-associated pericytes is identical to aminopeptidase N. J Neurochem 62: 2375-86.

Lai CH, Kuo KH (2005). The critical component to establish in vitro BBB model: Pericyte. Brain Res Brain Res $\operatorname{Rev}$ 50: 258-65.

Lamagna C, Bergers G (2006). The bone marrow constitutes a reservoir of pericyte progenitors. J Leukoc Biol 80: 677-81.

Larsson J, Goumans MJ, Sjostrand LJ, van Rooijen MA, Ward D, Leveen P, Xu X, ten Dijke P, Mummery CL, Karlsson S (2001). Abnormal angiogenesis but intact hematopoietic potential in TGF- $\beta$ type I receptor-deficient mice. EMBO J 20: 1663-73.

Lee TS, Hu KQ, Chao T, King GL (1989). Characterization of endothelin receptors and effects of endothelin on diacylglycerol and protein kinase C in retinal capillary pericytes. Diabetes 38: 1643-6.

Li DY, Sorensen LK, Brooke BS, Urness LD, Davis EC, Taylor DG, Boak BB, Wendel DP (1999). Defective angiogenesis in mice lacking endoglin. Science 284: 1534-7.

Li JL, Sainson RC, Shi W, Leek R, Harrington LS, Preusser M, Biswas S, Turley H, Heikamp E, Hainfellner JA, Harris AL (2007). Delta-like 4 Notch ligand regulates tumor angiogenesis, improves tumor vascular function, and promotes tumor growth in vivo. Cancer Res 67: 11244-53.

Li Q, Puro DG (2001). Adenosine activates ATP-sensitive $\mathrm{K}^{+}$currents in pericytes of rat retinal microvessels: role of A1 and A2a receptors. Brain Res 907: 93-9.

Lindahl P, Johansson BR, Leveen P, Betsholtz C (1997). Pericyte loss and microaneurysm formation in PDGF-B-deficient mice. Science 277: 242-5.

Lindskog H, Athley E, Larsson E, Lundin S, Hellstrom M, Lindahl P (2006). New insights to vascular smooth muscle cell and pericyte differentiation of mouse embryonic stem cells in vitro. Arterioscler Thromb 
Vasc Biol 26: 1457-64.

Liu H, Kennard S, Lilly B (2009). NOTCH3 expression is induced in mural cells through an autoregulatory loop that requires endothelial-expressed JAGGED1. Circ Res 104: 466-75.

Liu Y, Wada R, Yamashita T, Mi Y, Deng CX, Hobson JP, Rosenfeldt HM, Nava VE, Chae SS, Lee MJ, Liu CH, Hla T, Spiegel S, Proia RL (2000). Edg-1, the G protein-coupled receptor for sphingosine-1-phosphate, is essential for vascular maturation. $J$ Clin Invest 106: 951-61.

Lombard JH (2006). A novel mechanism for regulation of retinal blood flow by lactate: gap junctions, hypoxia, and pericytes. Am J Physiol Heart Circ Physiol 290: H921-2.

MacFadyen J, Savage K, Wienke D, Isacke CM (2007). Endosialin is expressed on stromal fibroblasts and CNS pericytes in mouse embryos and is downregulated during development. Gene Expr Patterns 7: 363-9.

Maisonpierre PC, Suri C, Jones PF, Bartunkova S, Wiegand SJ, Radziejewski C, Compton D, McClain J, Aldrich TH, Papadopoulos N, Daly TJ, Davis S, Sato TN, Yancopoulos GD (1997). Angiopoietin-2, a natural antagonist for Tie2 that disrupts in vivo angiogenesis. Science 277: 55-60.

Mathiisen TM, Lehre KP, Danbolt NC, Ottersen OP (2010). The perivascular astroglial sheath provides a complete covering of the brain microvessels: an electron microscopic 3D reconstruction. Glia 58: 1094-103.

Matsugi T, Chen Q, Anderson DR (1997). Contractile responses of cultured bovine retinal pericytes to angiotensin II. Arch Ophthalmol 115: 1281-5.

McGinty A, Scholfield CN, Liu WH, Anderson P, Hoey DE, Trimble ER (1999). Effect of glucose on endothelin-1-induced calcium transients in cultured bovine retinal pericytes. J Biol Chem 274:25250-3.

Mitchell TS, Bradley J, Robinson GS, Shima DT, Ng YS (2008). RGS5 expression is a quantitative measure of pericyte coverage of blood vessels. Angiogenesis 11: 141-51.

Morgan J, Muntoni F (2007). Mural cells paint a new picture of muscle stem cells. Nat Cell Biol 9: 249-51. Nakagawa S, Deli MA, Kawaguchi H, Shimizudani T, Shimono T, Kittel A, Tanaka K, Niwa M (2009). A new blood-brain barrier model using primary rat brain endothelial cells, pericytes and astrocytes. Neurochem Int 54: 253-63.

Nakagawa S, Deli MA, Nakao S, Honda M, Hayashi K, Nakaoke R, Kataoka Y, Niwa M (2007). Pericytes from brain microvessels strengthen the barrier integrity in primary cultures of rat brain endothelial cells. Cell 
Mol Neurobiol 27: 687-94.

Nakamura K, Kamouchi M, Kitazono T, Kuroda J, Matsuo R, Hagiwara N, Ishikawa E, Oobosi H, Ibayashi S, lida M (2008). Role of NHE1 in calcium signaling and cell proliferation in human CNS pericytes. Am J Physiol Heart Circ Physiol 294: H1700-1707.

Nakamura K, Kamouchi M, Kitazono T, Kuroda J, Shono Y, Hagiwara N, Ago T, Ooboshi H, Ibayashi S, lida M (2009). Amiloride inhibits hydrogen peroxide-induced $\mathrm{Ca}^{2+}$ responses in human CNS pericytes. Microvasc Res 77: 327-34.

Nayak RC, Berman AB, George KL, Eisenbarth GS, King GL (1988). A monoclonal antibody (3G5)-defined ganglioside antigen is expressed on the cell surface of microvascular pericytes. $J$ Exp Med 167: 1003-15.

Nehls V, Drenckhahn D (1991). Heterogeneity of microvascular pericytes for smooth muscle type $\alpha$-actin. $J$ Cell Biol 113: 147-54.

Nisancioglu MH, Mahoney WM, Jr., Kimmel DD, Schwartz SM, Betsholtz C, Genove G (2008). Generation and characterization of RGS5 mutant mice. Mol Cell Biol 28: 2324-31.

Nissen LJ, Cao R, Hedlund EM, Wang Z, Zhao X, Wetterskog D, Funa K, Brakenhielm E, Cao Y (2007). Angiogenic factors FGF2 and PDGF-BB synergistically promote murine tumor neovascularization and metastasis. J Clin Invest 117: 2766-77.

Noguera-Troise I, Daly C, Papadopoulos NJ, Coetzee S, Boland P, Gale NW, Lin HC, Yancopoulos GD, Thurston G (2006). Blockade of DIl4 inhibits tumour growth by promoting non-productive angiogenesis. Nature 444: 1032-7.

Nomura M, Yamagishi S, Harada S, Hayashi Y, Yamashima T, Yamashita J, Yamamoto H (1995). Possible participation of autocrine and paracrine vascular endothelial growth factors in hypoxia-induced proliferation of endothelial cells and pericytes. J Biol Chem 270: 28316-24.

Oh SP, Seki T, Goss KA, Imamura T, Yi Y, Donahoe PK, Li L, Miyazono K, ten Dijke P, Kim S, Li E (2000). Activin receptor-like kinase 1 modulates transforming growth factor $-\beta 1$ signaling in the regulation of angiogenesis. Proc Natl Acad Sci U S A 97: 2626-31.

Oishi K, Kamiyashiki T, Ito Y (2007). Isometric contraction of microvascular pericytes from mouse brain parenchyma. Microvasc Res 73: 20-8.

Okazaki T, Ni A, Baluk P, Ayeni OA, Kearley J, Coyle AJ, Humbles A, McDonald DM (2009). Capillary defects 
and exaggerated inflammatory response in the airways of EphA2-deficient mice. Am J Pathol 174: 2388-99.

Ozerdem U, Stallcup WB (2003). Early contribution of pericytes to angiogenic sprouting and tube formation. Angiogenesis 6: 241-9.

Ozerdem U, Stallcup WB (2004). Pathological angiogenesis is reduced by targeting pericytes via the NG2 proteoglycan. Angiogenesis 7: 269-76.

Paik JH, Skoura A, Chae SS, Cowan AE, Han DK, Proia RL, Hla T (2004). Sphingosine 1-phosphate receptor regulation of N-cadherin mediates vascular stabilization. Genes Dev 18: 2392-403.

Pallone TL, Huang JM (2002). Control of descending vasa recta pericyte membrane potential by angiotensin II. Am J Physiol Renal Physiol 282: F1064-74.

Pallone TL, Silldorff EP, Zhang Z (2000). Inhibition of calcium signaling in descending vasa recta endothelia by ANG II. Am J Physiol Heart Circ Physiol 278: H1248-55.

Paquet-Fifield S, Schluter H, Li A, Aitken T, Gangatirkar P, Blashki D, Koelmeyer R, Pouliot N, Palatsides M, Ellis S, Brouard N, Zannettino A, Saunders N, Thompson N, Li J, Kaur P (2009). A role for pericytes as microenvironmental regulators of human skin tissue regeneration. J Clin Invest 119: 2795-806.

Parkinson FE, Hacking C (2005). Pericyte abundance affects sucrose permeability in cultures of rat brain microvascular endothelial cells. Brain Res 1049: 8-14.

Patan S (1998). TIE1 and TIE2 receptor tyrosine kinases inversely regulate embryonic angiogenesis by the mechanism of intussusceptive microvascular growth. Microvasc Res 56: 1-21.

Peppiatt CM, Howarth C, Mobbs P, Attwell D (2006). Bidirectional control of CNS capillary diameter by pericytes. Nature 443: 700-4.

Persidsky Y, Ramirez SH, Haorah J, Kanmogne GD (2006). Blood-brain barrier: structural components and function under physiologic and pathologic conditions. J Neuroimmune Pharmacol 1: 223-36.

Piquer-Gil M, Garcia-Verdugo JM, Zipancic I, Sanchez MJ, Alvarez-Dolado M (2009). Cell fusion contributes to pericyte formation after stroke. J Cereb Blood Flow Metab 29: 480-5.

Puri MC, Partanen J, Rossant J, Bernstein A (1999). Interaction of the TEK and TIE receptor tyrosine kinases during cardiovascular development. Development 126: 4569-80.

Puro DG (2007). Physiology and pathobiology of the pericyte-containing retinal microvasculature: new developments. Microcirculation 14: 1-10. 
Rajantie I, Ilmonen M, Alminaite A, Ozerdem U, Alitalo K, Salven P (2004). Adult bone marrow-derived cells recruited during angiogenesis comprise precursors for periendothelial vascular mural cells. Blood 104: 2084-6.

Reddy K, Cao Y, Zhou Z, Yu L, Jia SF, Kleinerman ES (2008). VEGF165 expression in the tumor microenvironment influences the differentiation of bone marrow-derived pericytes that contribute to the Ewing's sarcoma vasculature. Angiogenesis 11: 257-67.

Reddy K, Zhou Z, Schadler K, Jia SF, Kleinerman ES (2008). Bone marrow subsets differentiate into endothelial cells and pericytes contributing to Ewing's tumor vessels. Mol Cancer Res 6: 929-36.

Reinmuth N, Liu W, Ahmad SA, Fan F, Stoeltzing O, Parikh AA, Bucana CD, Gallick GE, Nickols MA, Westlin WF, Ellis LM (2003). avß3 integrin antagonist S247 decreases colon cancer metastasis and angiogenesis and improves survival in mice. Cancer Res 63: 2079-87.

Rouget C (1873). Memoire sur le developpement, la structure et les proprietes physiologiques des capillaries sanguins et lymphatiques. Arch Phsyiol Normale Pathol 5: 603-61.

Rouget C (1879). Sur la contractilite des capillaires sanguins. CR Acad Sci 88.

Rucker HK, Wynder HJ, Thomas WE (2000). Cellular mechanisms of CNS pericytes. Brain Res Bull 51: 363-9.

Sainson RC, Harris AL (2007). Anti-DII4 therapy: can we block tumour growth by increasing angiogenesis? Trends Mol Med 13: 389-95.

Sainson RC, Harris AL (2008). Regulation of angiogenesis by homotypic and heterotypic notch signalling in endothelial cells and pericytes: from basic research to potential therapies. Angiogenesis 11: 41-51.

Sakagami K, Wu DM, Puro DG (1999). Physiology of rat retinal pericytes: modulation of ion channel activity by serum-derived molecules. J Physiol 521 Pt 3: 637-50.

Salvucci O, Maric D, Economopoulou M, Sakakibara S, Merlin S, Follenzi A, Tosato G (2009). EphrinB reverse signaling contributes to endothelial and mural cell assembly into vascular structures. Blood 114: $1707-16$.

Sato TN, Tozawa Y, Deutsch U, Wolburg-Buchholz K, Fujiwara Y, Gendron-Maguire M, Gridley T, Wolburg H, Risau W, Qin Y (1995). Distinct roles of the receptor tyrosine kinases Tie-1 and Tie-2 in blood vessel formation. Nature 376: 70-4.

Sato Y, Rifkin DB (1989). Inhibition of endothelial cell movement by pericytes and smooth muscle cells: 
activation of a latent transforming growth factor- $\beta$ 1-like molecule by plasmin during co-culture. $J$ Cell Biol 109: 309-15.

Sato Y, Tsuboi R, Lyons R, Moses H, Rifkin DB (1990). Characterization of the activation of latent TGF- $\beta$ by co-cultures of endothelial cells and pericytes or smooth muscle cells: a self-regulating system. J Cell Biol 111: 757-63.

Saunders WB, Bohnsack BL, Faske JB, Anthis NJ, Bayless KJ, Hirschi KK, Davis GE (2006). Coregulation of vascular tube stabilization by endothelial cell TIMP-2 and pericyte TIMP-3. J Cell Biol 175: 179-91.

Scehnet JS, Jiang W, Kumar SR, Krasnoperov V, Trindade A, Benedito R, Djokovic D, Borges C, Ley EJ, Duarte A, Gill PS (2007). Inhibition of DII4-mediated signaling induces proliferation of immature vessels and results in poor tissue perfusion. Blood 109: 4753-60.

Schlingemann RO, Oosterwijk E, Wesseling P, Rietveld FJ, Ruiter DJ (1996). Aminopeptidase A is a constituent of activated pericytes in angiogenesis. J Pathol 179: 436-42.

Semela D, Das A, Langer D, Kang N, Leof E, Shah V (2008). Platelet-derived growth factor signaling through ephrin-B2 regulates hepatic vascular structure and function. Gastroenterology 135: 671-9.

Shepro D, Morel NM (1993). Pericyte physiology. FASEB J 7: 1031-8.

Shih SC, Ju M, Liu N, Mo JR, Ney JJ, Smith LE (2003). Transforming growth factor $\beta 1$ induction of vascular endothelial growth factor receptor 1: mechanism of pericyte-induced vascular survival in vivo. Proc Natl Acad Sci U S A 100: 15859-64.

Shim WS, Ho IA, Wong PE (2007). Angiopoietin: a TIE(d) balance in tumor angiogenesis. Mol Cancer Res 5: 655-65.

Shimizu F, Sano Y, Maeda T, Abe MA, Nakayama H, Takahashi R, Ueda M, Ohtsuki S, Terasaki T, Obinata M, Kanda T (2008). Peripheral nerve pericytes originating from the blood-nerve barrier expresses tight junctional molecules and transporters as barrier-forming cells. J Cell Physiol 217: 388-99.

Sieczkiewicz GJ, Herman IM (2003). TGF- $\beta 1$ signaling controls retinal pericyte contractile protein expression. Microvasc Res 66: 190-6.

Silva R, D'Amico G, Hodivala-Dilke KM, Reynolds LE (2008). Integrins: the keys to unlocking angiogenesis. Arterioscler Thromb Vasc Biol 28: 1703-13.

Simonavicius N, Robertson D, Bax DA, Jones C, Huijbers IJ, Isacke CM (2008). Endosialin (CD248) is a marker of tumor-associated pericytes in high-grade glioma. Mod Pathol 21: 308-15. 
Smith MW, Gumbleton M (2006). Endocytosis at the blood-brain barrier: from basic understanding to drug delivery strategies. J Drug Target 14: 191-214.

Song N, Huang Y, Shi H, Yuan S, Ding Y, Song X, Fu Y, Luo Y (2009). Overexpression of platelet-derived growth factor-BB increases tumor pericyte content via stromal-derived factor-1a/CXCR4 axis. Cancer Res 69: 6057-64.

Song S, Ewald AJ, Stallcup W, Werb Z, Bergers G (2005). PDGFRß+ perivascular progenitor cells in tumours regulate pericyte differentiation and vascular survival. Nat Cell Biol 7: 870-9.

Sorensen LK, Brooke BS, Li DY, Urness LD (2003). Loss of distinct arterial and venous boundaries in mice lacking endoglin, a vascular-specific TGF $\beta$ coreceptor. Dev Biol 261: 235-50.

Stallcup WB, Huang FJ (2008). A role for the NG2 proteoglycan in glioma progression. Cell Adh Migr 2: 192-201.

Stockmann C, Doedens A, Weidemann A, Zhang N, Takeda N, Greenberg Jl, Cheresh DA, Johnson RS (2008). Deletion of vascular endothelial growth factor in myeloid cells accelerates tumorigenesis. Nature 456: 814-8.

Stratman AN, Malotte KM, Mahan RD, Davis MJ, Davis GE (2009). Pericyte recruitment during vasculogenic tube assembly stimulates endothelial basement membrane matrix formation. Blood 114: 5091-101.

Stratman AN, Saunders WB, Sacharidou A, Koh W, Fisher KE, Zawieja DC, Davis MJ, Davis GE (2009). Endothelial cell lumen and vascular guidance tunnel formation requires MT1-MMP-dependent proteolysis in 3-dimensional collagen matrices. Blood 114: 237-47.

Sundberg C, Friman T, Hecht LE, Kuhl C, Solomon KR (2009). Two different PDGF $\beta$-receptor cohorts in human pericytes mediate distinct biological endpoints. Am J Pathol 175: 171-89.

Sundberg C, Kowanetz M, Brown LF, Detmar M, Dvorak HF (2002). Stable expression of angiopoietin-1 and other markers by cultured pericytes: phenotypic similarities to a subpopulation of cells in maturing vessels during later stages of angiogenesis in vivo. Lab Invest 82: 387-401.

Suri C, Jones PF, Patan S, Bartunkova S, Maisonpierre PC, Davis S, Sato TN, Yancopoulos GD (1996). Requisite role of angiopoietin-1, a ligand for the TIE2 receptor, during embryonic angiogenesis. Cell 87: $1171-80$.

Takagi H, King GL, Aiello LP (1996). Identification and characterization of vascular endothelial growth factor receptor (FIt) in bovine retinal pericytes. Diabetes 45: 1016-23. 
Takahashi K, Brooks RA, Kanse SM, Ghatei MA, Kohner EM, Bloom SR (1989). Production of endothelin 1 by cultured bovine retinal endothelial cells and presence of endothelin receptors on associated pericytes. Diabetes 38: 1200-2.

Takata F, Dohgu S, Yamauchi A, Sumi N, Nakagawa S, Naito M, Tsuruo T, Shuto H, Kataoka Y (2007). Inhibition of transforming growth factor- $\beta$ production in brain pericytes contributes to cyclosporin A-induced dysfunction of the blood-brain barrier. Cell Mol Neurobiol 27: 317-28.

Takuwa Y, Okamoto Y, Yoshioka K, Takuwa N (2008). Sphingosine-1-phosphate signaling and biological activities in the cardiovascular system. Biochim Biophys Acta 1781: 483-8.

Tang W, Zeve D, Suh JM, Bosnakovski D, Kyba M, Hammer RE, Tallquist MD, Graff JM (2008). White fat progenitor cells reside in the adipose vasculature. Science 322: 583-6.

Thomas WE (1999). Brain macrophages: on the role of pericytes and perivascular cells. Brain Res Brain Res Rev 31: 42-57.

Tigges U, Hyer EG, Scharf J, Stallcup WB (2008). FGF2-dependent neovascularization of subcutaneous Matrigel plugs is initiated by bone marrow-derived pericytes and macrophages. Development 135 : 523-32.

Tillet E, Vittet D, Feraud O, Moore R, Kemler R, Huber P (2005). N-cadherin deficiency impairs pericyte recruitment, and not endothelial differentiation or sprouting, in embryonic stem cell-derived angiogenesis. Exp Cell Res 310: 392-400.

Traktuev DO, Merfeld-Clauss S, Li J, Kolonin M, Arap W, Pasqualini R, Johnstone BH, March KL (2008). A population of multipotent CD34-positive adipose stromal cells share pericyte and mesenchymal surface markers, reside in a periendothelial location, and stabilize endothelial networks. Circ Res 102: 77-85.

Urness LD, Sorensen LK, Li DY (2000). Arteriovenous malformations in mice lacking activin receptor-like kinase-1. Nat Genet 26: 328-31.

van Hinsbergh VW, Engelse MA, Quax PH (2006). Pericellular proteases in angiogenesis and vasculogenesis. Arterioscler Thromb Vasc Biol 26: 716-28.

Verbeek MM, Otte-Holler I, Wesseling P, Ruiter DJ, de Waal RM (1994). Induction of $\alpha$-smooth muscle actin expression in cultured human brain pericytes by transforming growth factor- $\beta$ 1. Am J Pathol 144: 372-82. 
Vikkula M, Boon LM, Carraway KL, 3rd, Calvert JT, Diamonti AJ, Goumnerov B, Pasyk KA, Marchuk DA, Warman ML, Cantley LC, Mulliken JB, Olsen BR (1996). Vascular dysmorphogenesis caused by an activating mutation in the receptor tyrosine kinase TIE2. Cell 87: 1181-90.

Virgintino D, Girolamo F, Errede M, Capobianco C, Robertson D, Stallcup WB, Perris R, Roncali L (2007). An intimate interplay between precocious, migrating pericytes and endothelial cells governs human fetal brain angiogenesis. Angiogenesis 10: 35-45.

von Tell D, Armulik A, Betsholtz C (2006). Pericytes and vascular stability. Exp Cell Res 312: 623-9.

Wakisaka M, Kitazono T, Kato M, Nakamura U, Yoshioka M, Uchizono Y, Yoshinari M (2001). Sodium-coupled glucose transporter as a functional glucose sensor of retinal microvascular circulation. Circ Res 88: 1183-8.

Wakui S, Furusato M, Muto T, Ohshige H, Takahashi H, Ushigome S (1997). Transforming growth factor- $\beta$ and urokinase plasminogen activator presents at endothelial cell-pericyte interdigitation in human granulation tissue. Microvasc Res 54: 262-9.

Wakui S, Yokoo K, Muto T, Suzuki Y, Takahashi H, Furusato M, Hano H, Endou H, Kanai Y (2006). Localization of Ang-1, -2, Tie-2, and VEGF expression at endothelial-pericyte interdigitation in rat angiogenesis. Lab Invest 86: 1172-84.

Wang YL, Hui YN, Guo B, Ma JX (2007). Strengthening tight junctions of retinal microvascular endothelial cells by pericytes under normoxia and hypoxia involving angiopoietin-1 signal way. Eye 21: 1501-10.

Watanabe S, Morisaki N, Tezuka M, Fukuda K, Ueda S, Koyama N, Yokote K, Kanzaki T, Yoshida S, Saito Y (1997). Cultured retinal pericytes stimulate in vitro angiogenesis of endothelial cells through secretion of a fibroblast growth factor-like molecule. Atherosclerosis 130: 101-7.

Winkler F, Kozin SV, Tong RT, Chae SS, Booth MF, Garkavtsev I, Xu L, Hicklin DJ, Fukumura D, di Tomaso E, Munn LL, Jain RK (2004). Kinetics of vascular normalization by VEGFR2 blockade governs brain tumor response to radiation: role of oxygenation, angiopoietin-1, and matrix metalloproteinases. Cancer Cell 6: 553-63.

Wu DM, Kawamura H, Sakagami K, Kobayashi M, Puro DG (2003). Cholinergic regulation of pericyte-containing retinal microvessels. Am J Physiol Heart Circ Physiol 284: H2083-90.

Yamanishi S, Katsumura K, Kobayashi T, Puro DG (2006). Extracellular lactate as a dynamic vasoactive signal in the rat retinal microvasculature. Am J Physiol Heart Circ Physiol 290: H925-34. 
Yan Q, Sage EH (1998). Transforming growth factor- $\beta 1$ induces apoptotic cell death in cultured retinal endothelial cells but not pericytes: association with decreased expression of p21waf1/cip1. J Cell Biochem 70: 70-83.

Yemisci M, Gursoy-Ozdemir Y, Vural A, Can A, Topalkara K, Dalkara T (2009). Pericyte contraction induced by oxidative-nitrative stress impairs capillary reflow despite successful opening of an occluded cerebral artery. Nat Med 15: 1031-7.

Yonekura H, Sakurai S, Liu X, Migita H, Wang H, Yamagishi S, Nomura M, Abedin MJ, Unoki H, Yamamoto Y, Yamamoto $\mathrm{H}$ (1999). Placenta growth factor and vascular endothelial growth factor $\mathrm{B}$ and $\mathrm{C}$ expression in microvascular endothelial cells and pericytes. Implication in autocrine and paracrine regulation of angiogenesis. J Biol Chem 274: 35172-8.

Zhang J, Cao R, Zhang Y, Jia T, Cao Y, Wahlberg E (2009). Differential roles of PDGFR- $\alpha$ and PDGFR- $\beta$ in angiogenesis and vessel stability. FASEB J 23: 153-63.

Zimmerman K (1923). Der Peinere Bau der Blutcapillaren. A Anat Entwicklungsgesch 68: 29-109.

Zlokovic BV (2006). Remodeling after stroke. Nat Med 12: 390-1.

Zlokovic BV (2008). The blood-brain barrier in health and chronic neurodegenerative disorders. Neuron 57: $178-201$.

Zozulya A, Weidenfeller C, Galla HJ (2008). Pericyte-endothelial cell interaction increases MMP-9 secretion at the blood-brain barrier in vitro. Brain Res 1189: 1-11. 


\section{Table 1. Pericyte markers and factors involved in the pericyte functions}

\begin{tabular}{|c|c|}
\hline Cell markers & $\begin{array}{l}\text { PDGFR- } \beta \text {, NG2, } \alpha \text { smooth muscle actin, desmin, vimentin, RGS-5, 3G5, } \\
\text { Kir6.1, nestin, Sca-1, aminopeptidases A and N, high molecular weight } \\
\text { melanoma-associated antigen, alkaline phophatase, V-glutamyl } \\
\text { transpeptidase, butyrylcholinesterase, FcR, CD4, CD11b, CD34, CD140a, } \\
\text { MHC class I.II }\end{array}$ \\
\hline \multicolumn{2}{|r|}{ (1) } \\
\hline Regulation of capillary flow & $\begin{array}{l}\text { ATP, cholinergic agonists, adrenergic agonists, histamine, serotonin, } \\
\text { angiotensin II, endothelin-1, atrial natriuretic peptide, reactive oxygen } \\
\text { species }\end{array}$ \\
\hline Angiogenesis & 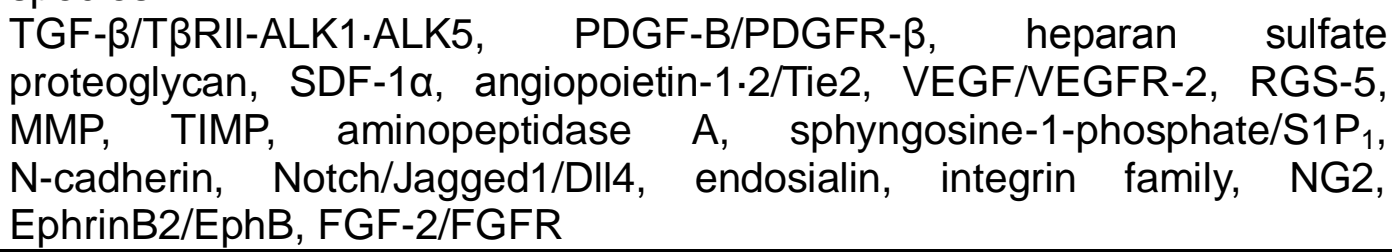 \\
\hline
\end{tabular}

Table 2. Pericytes in the formation of blood brain barrier

\begin{tabular}{|c|c|}
\hline Proposed mechanisms & References \\
\hline Tightening inter-endothelial junction (physical barrier) & (Edelman et al 2006) \\
\hline Production of extracellular matrices & (Hartmann et al 2007) \\
\hline Regulation of endothelial tight junction proteins & (Kim et al 2009; Nakagawa et al 2009) \\
\hline & $\begin{array}{l}\text { Pericytes strengthen barrier function by } \\
\text { upregulating tight junction proteins via } \\
\text { angiopoietin-1 (Hori et al 2004; Wang et al } \\
\text { 2007; Kim et al 2008) and TGF }-1 \text { (Dohgu et } \\
\text { al 2005; Takata et al 2007). }\end{array}$ \\
\hline Regulation of endothelial transport systems & (Takata et al 2007) \\
\hline Regulation of endothelial MMP & (Virgintino et al 2007; Zozulya et al 2008) \\
\hline $\begin{array}{l}\text { Expression of tight junction proteins } \\
\text { barrier-related transporters in the pericytes }\end{array}$ & (Bendayan et al 2006; Shimizu et al 2008) \\
\hline
\end{tabular}


(Figure 1)

A

\section{Neuron}

Endothelial cell

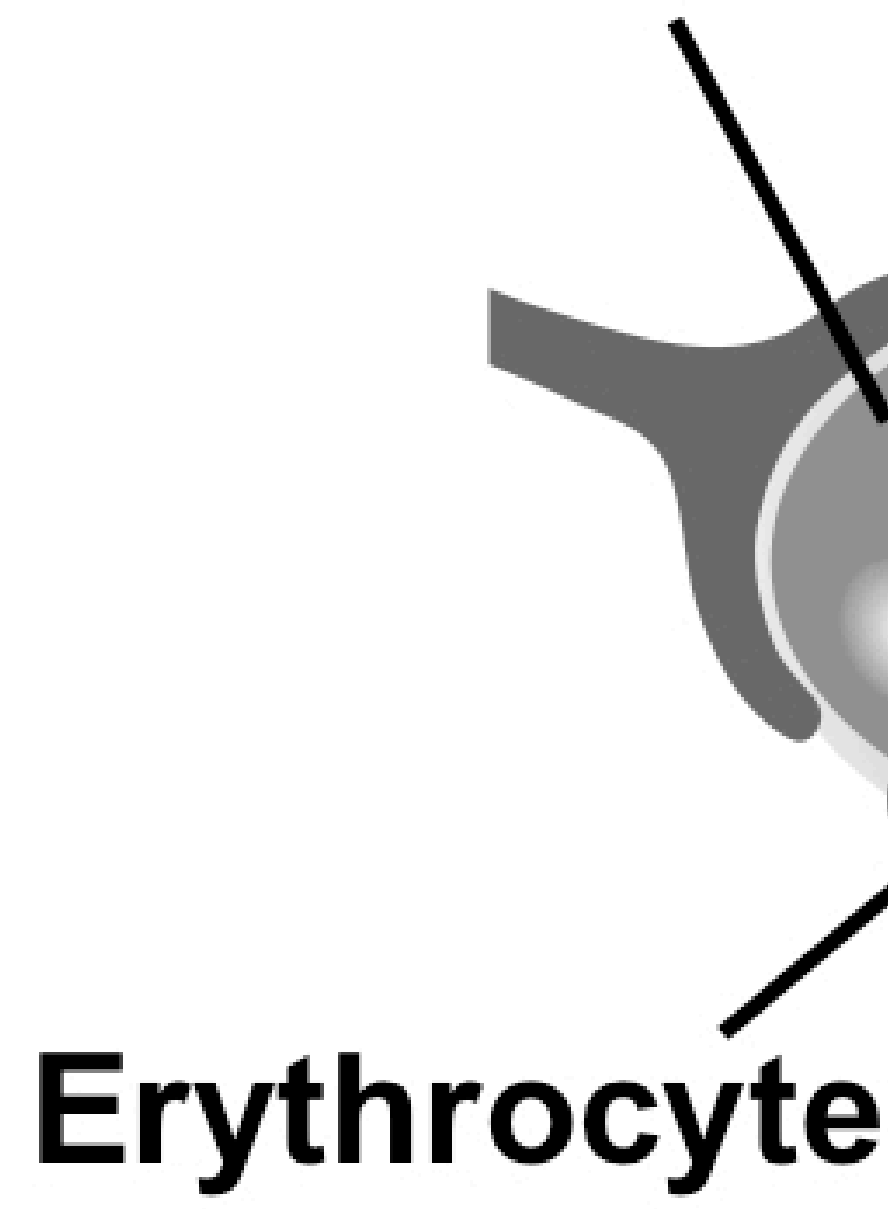

Pericyte

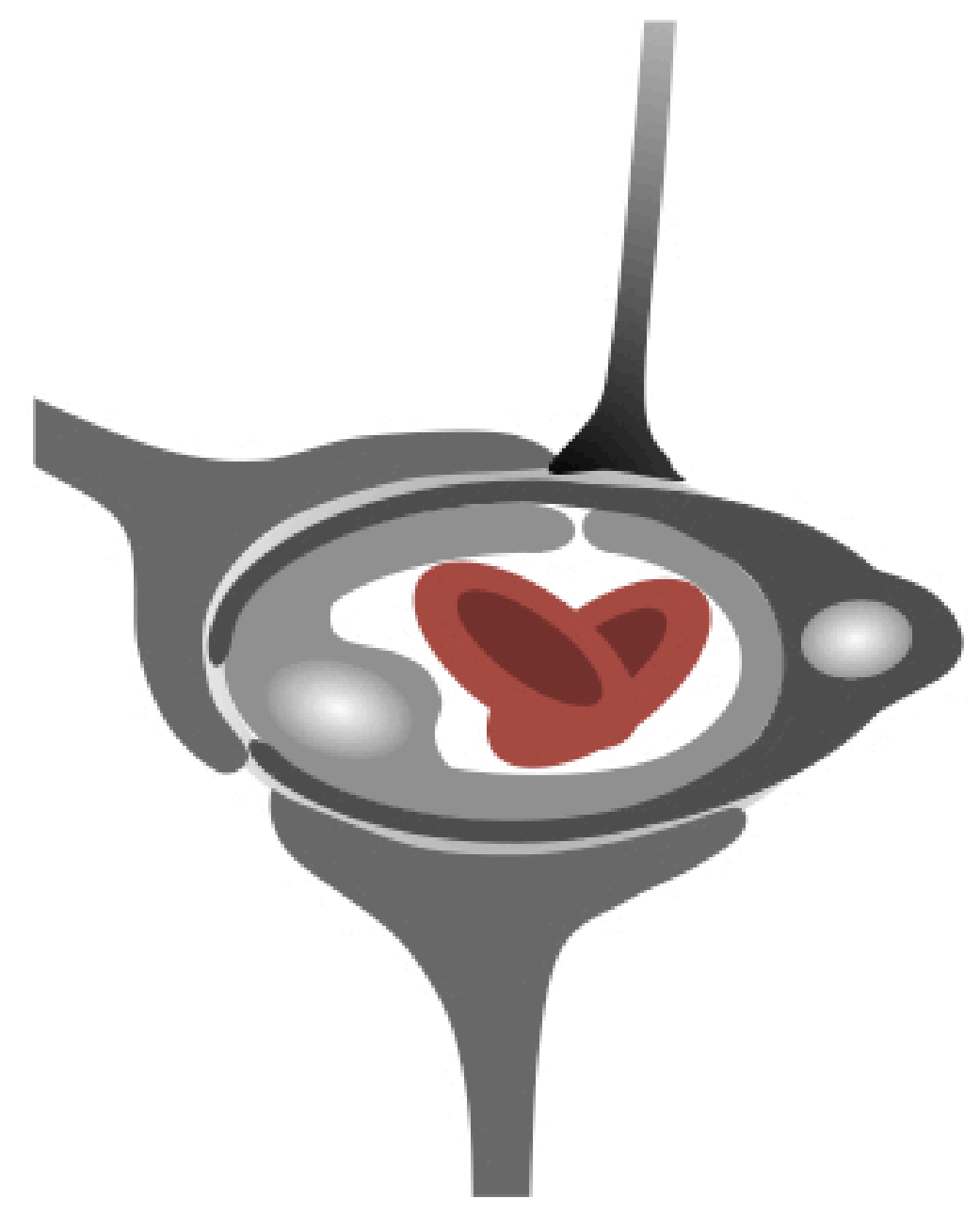

Astrocytic endfoot 
(Figure 2)

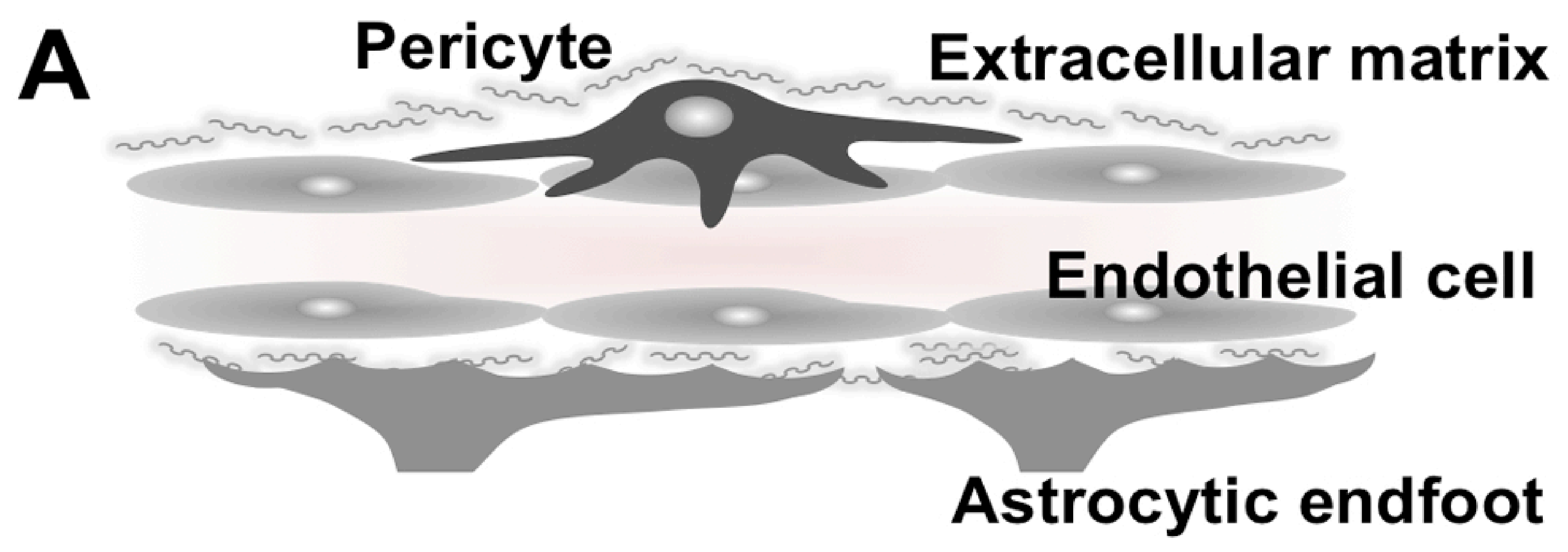

B

Pericyte

\section{Endothelial cell}


(Figure 3)

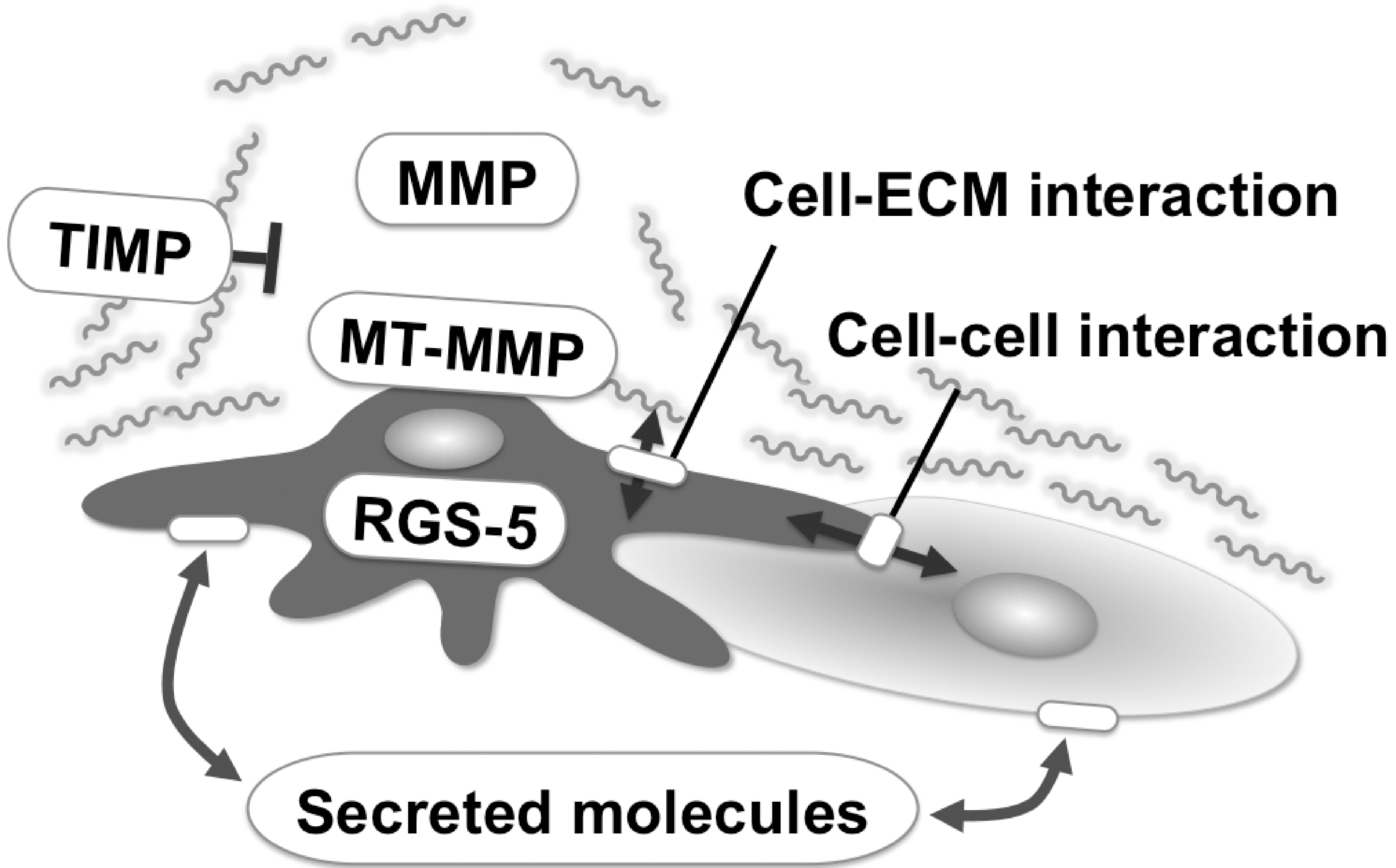


(Figure 4)

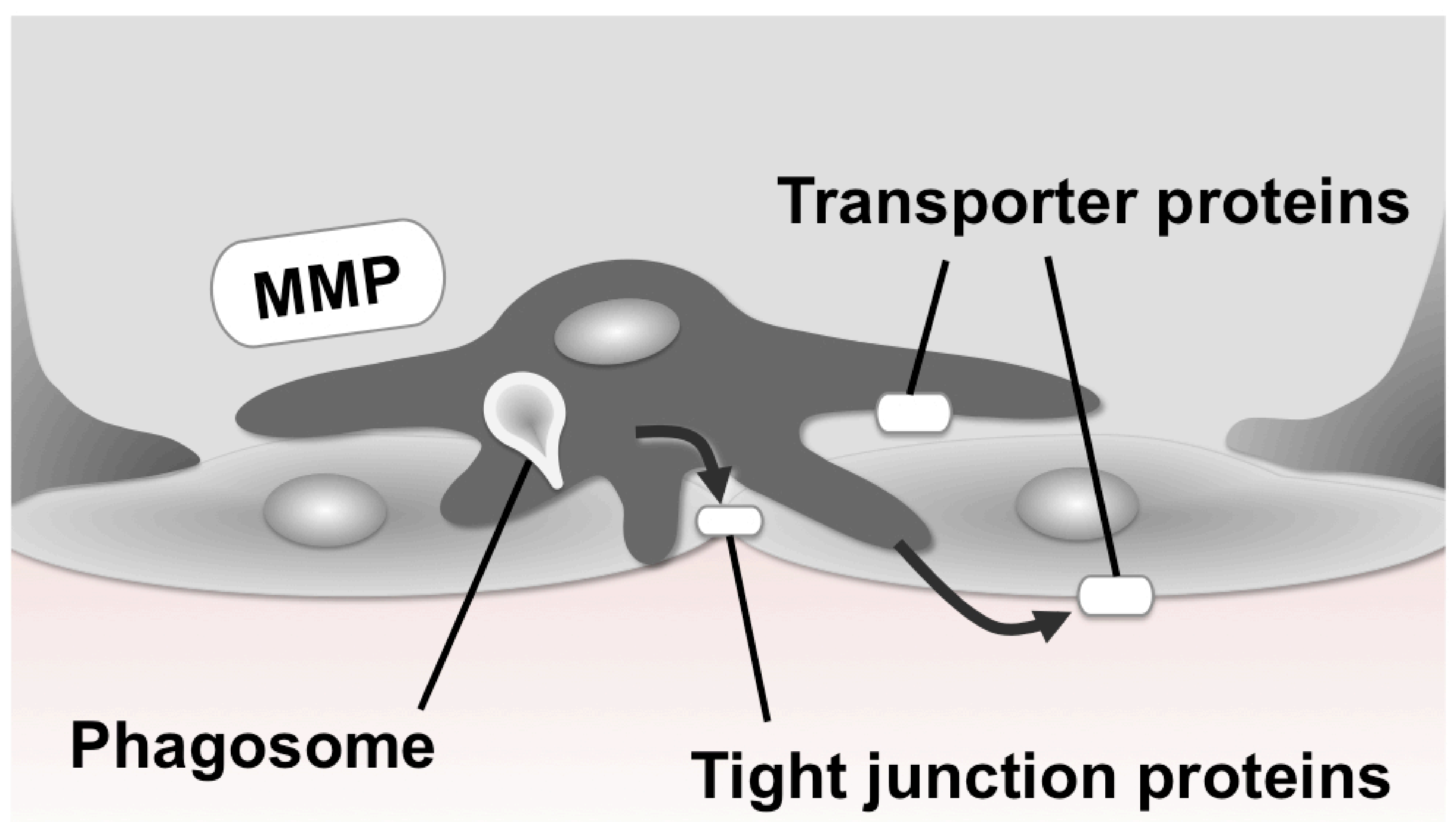


(Figure 5)

Bone marrow

\section{Local environment}

Mesenchymal

stem cell

Smooth muscle cell

Fibroblast

Osteocyte

Adipocyte

Chondrocyte

Pericyte

$?$ progenitor cell

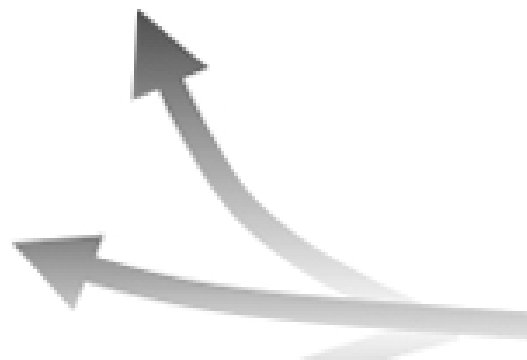

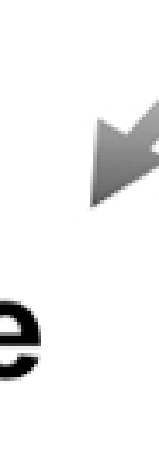

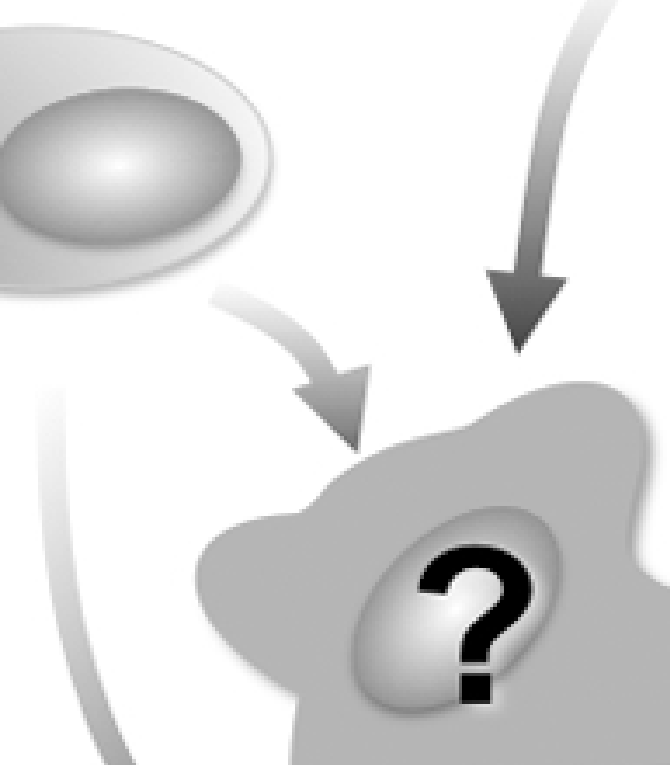

(

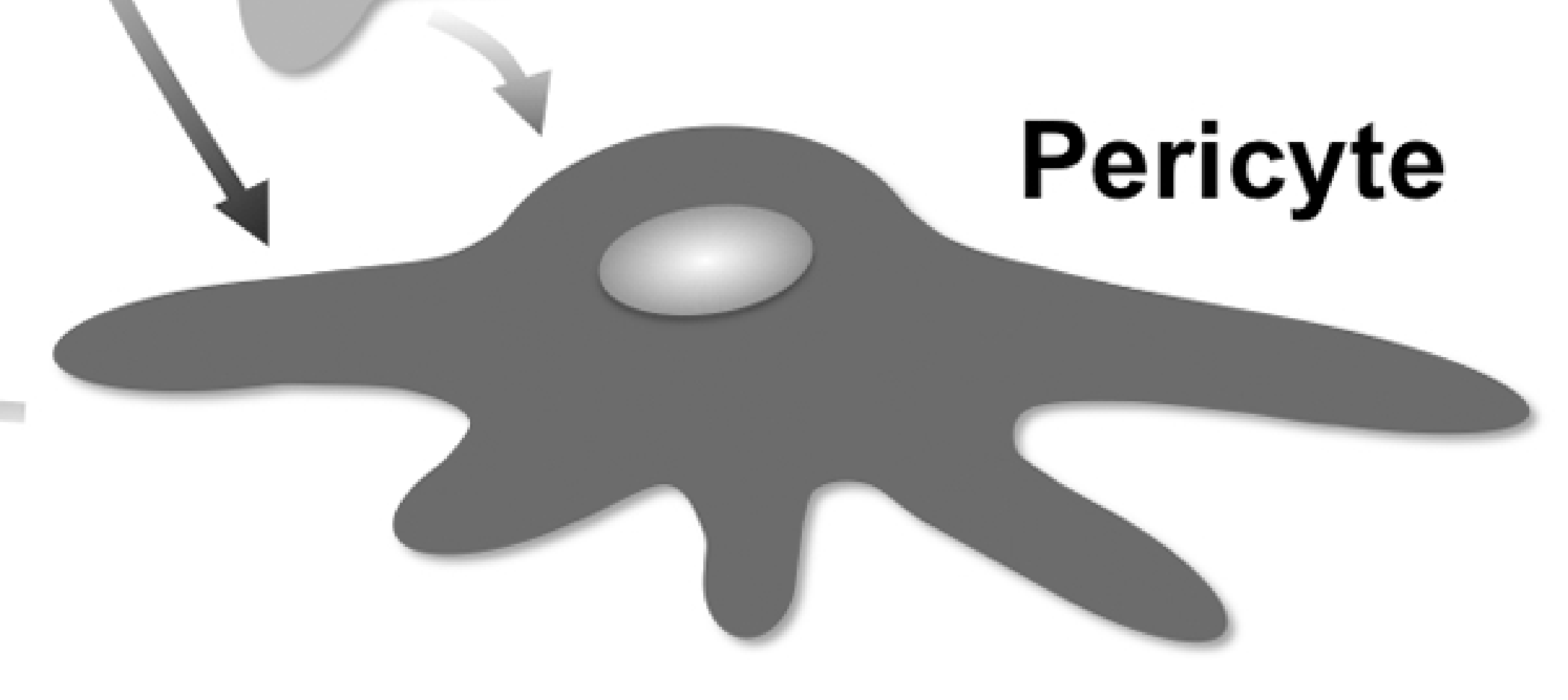

